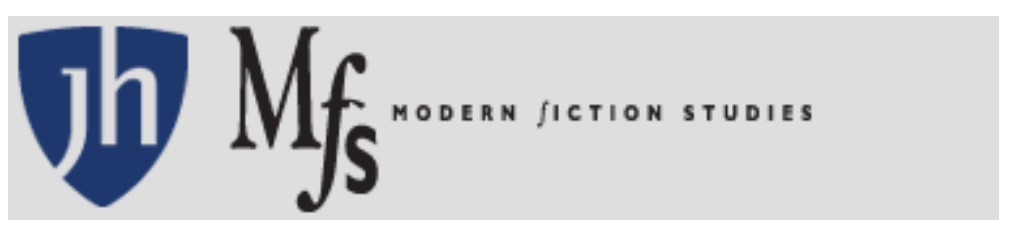

\title{
Cultivating the Classical Style: The Stanford-Denver Creative Writing Axis
}

\begin{tabular}{|r|l|}
\hline Journal: & MFS Modern Fiction Studies \\
\hline Manuscript ID & MFS-2018-0145.R1 \\
\hline Manuscript Type: & Original Article \\
\hline Authors: & $\begin{array}{l}\text { John Williams, Edward Loomis, Evan Connell, Gordon Lish, Raymond } \\
\text { Carver }\end{array}$ \\
\hline Keywords: & Twentieth Century, American fiction, Regionalism \\
\hline Abstract: & $\begin{array}{l}\text { Recent scholarship has done much to reveal the influence of the } \\
\text { institutionalisation of creative writing on US literary culture in the post } \\
\text { World War II. This article seeks to contribute to this emergent field by } \\
\text { drawing attention to the distinct form this took in key institutional sites } \\
\text { at Stanford University and the University of Denver between 1940 and } \\
\text { 1960. This "Stanford-Denver axis" served to retrieve and develop a } \\
\text { "classical style" of prose composition that influenced, among others, key } \\
\text { figures of post-war US literary culture such as Evan Connell, John } \\
\text { Williams, Gordon Lish and Raymond Carver. }\end{array}$ \\
\hline
\end{tabular}

\section{SCHOLARONE ${ }^{\text {m }}$ Manuscripts}




\section{Cultivating the Classical Style: The Stanford-Denver}

\section{Creative Writing Axis}

\section{The Early Twentieth Century Revival of Literary Classicism}

The notion of a "revival" of a classical artistic style is underpinned by an obvious irony. "What we call classical”, as Hans-Georg Gadamer writes, “...is a consciousness of something enduring, of significance that cannot be lost and is independent of all the circumstances of time, in which we call something 'classical'-a kind of timeless present that is contemporaneous with every other age" (Gadamer 256). Such an artistic style, impervious to the whims of time and trend, can never be "revived" as it "cannot be lost" and hence "endures" by definition. The classical literary style has its own reasonably specific historical roots, of course, in theories and modes of poetry, drama and rhetoric originating in antiquity. However, notwithstanding the claims that would appear to be embedded at the definitional level, classicism has also been subject to several moments of revival, most expansively during the Renaissance but also as a reactive engagement with cultural currents of the modern era.

Understandings of the classical literary style, as they have come down to us, privilege precise language, impersonal register, and formal coherence. More broadly, as Steven Shankman indicates, a classical work of literature, in the modern context, seeks to restore senses of exactitude, harmony and order undermined by looser realist or naturalist modes and the tendencies of modernist literature towards abstraction or irrationalism. Such a work can be defined as

a compelling, formally coherent, and rationally defensible rep- 
resentation that resists being reduced to the mere recording of material reality, on the one hand, or to the bare exemplification of an abstract philosophical precept, on the other (Shankman, xiii).

The mainstream of the twentieth-century classical revival has a number of tributaries but, in the Anglo-American literary context, a key development is the emergence of the New Criticism in the 1920s and 1930s. This was informed by the English critic T.E. Hulme's distinction between "classical" and "romantic" poetics. In his essay "Romanticism and Classicism" (1911), Hulme outlined an aesthetic premised on a fresh articulation of the latter tradition-a "new classicism"-defined primarily in terms of a repudiation of Romanticism. Central to both conceptions, he argued, is an understanding of human nature. For the Romantic, "man is intrinsically good, spoilt by nature"; the classical view, by contrast, conceives of human nature as "intrinsically limited, but disciplined by order and tradition to something fairly decent” (Hulme 117).

Such understandings, transplanted into the aesthetic sphere, generate a classical poetic style disciplined by the weight of tradition and ordered by its "faithful[ness] to the conception of a limit". Romantic modes of expression, on the other hand, reject formal and thematic constraints-Hulme observes disdainfully of romantic poetry, in this respect, the presence of "the word infinite in every other line" (120) - and instead privilege the passionate over the dispassionate; figurative over non-figurative language; emotion over reason. Hulme believed Romanticism to have been the dominant movement of the previous century but he also felt that it was about to undergo a salutary challenge from a "coming classical reaction" (119).

The objective of poetry, for Hulme, as opposed to the Romantic's undisciplined flights into untethered metaphor and metaphysical obscurantism, should be "accurate, precise and definite description" underwritten by a more modest conception of human nature. Poetry should be an exact but also an exacting art that 
requires great application-a "state of tension or concentration of mind" that, for example, does not reject metaphor per se but demands that the poet and critic attend to those frequent moments in post-Romantic poetry when metaphorical expressions fail "to convey a physical thing and become abstract counters" (121). After World War I, Hulme was to be proven at least partially correct though the "reaction" he predicted would be complicated by the strong and varied currents of literary modernism that would also evolve alongside—and sometimes within — the classical literary revival. In addition the impact of the "new classicism" would find expression via powerful and complex means of institutional embodiment that Hulme could not have foreseen.

\section{New Humanism - New Criticism}

T.S. Eliot would undoubtedly be the best known among the younger critics to embrace or "convert" to classicism. ${ }^{1}$ However, there is a strong case to be made that the impact of this recovery among the home-based American proponents of the "New Criticism" was ultimately more far reaching. Hulme's prophesy that "a period of dry, hard, classical verse" (119) was about to dawn was undoubtedly vindicated in the work of a group of poet-critics who were firmly ensconced in several major university English departments by the end of World War II. New Critics such as John Crowe Ransom, Allan Tate, Cleanth Brooks and Robert Penn Warren, all of whom were from and, initially at least, based in the South, fused the role of poet and critic and embraced a formalism that sought to dislodge the institutional power of established literary scholarship. As opposed to approaching literary interpretation via issues of biography, influence, and/or historical context the New Critics famously sought to assess the primary text in its own terms. The key was to identify, in Ransom's terminology, a work's "ontological" status by refusing to detach feeling from thought thereby recognising poetry's unique capacity to apprehend the world and human 
experience in precise and accurate language. Such formalism was also incarnated in the defiantly rational structuring and deliberate diction of the poetry, fiction and criticism produced by these figures in their time.

The New Critics were also major players among the wave of poet-critics that accrued significant cultural capital during the postwar years when English and Creative Writing departments became the institutional hubs of US literary life. In place of the independently financed "little magazines" and small coteries of literary scholars of the 1920s, the New Criticism appealed to grant-awarding foundations, new institutionally based "critical quarterlies", and expanding graduate student programs in a new era of mass higher education. As Evan Kindley argues, citing Ransom's 1948 proposal to the Rockefeller Foundation to fund the establishment of the Kenyon School of English, the aim was the creation of institutions "dedicated...to the cultivation of a specific cadre of nonelite, undereducated readers, working with the raw material of the hundreds of young soldiers back from the war with a thirst for literature" (Kindley 138). Such students were confronted with text books such as Brooks and Warren's Understanding Poetry (1938) and Understanding Fiction (1943) that served to popularise the technical formalism of the New Criticism.

The establishment of this institutional basis for a criticism informed by classical precepts was rendered less arduous, nonetheless, as a result of the impact of a cluster of university based intellectuals dubbed the New Humanists. With Irving Babbitt as their chief spokesman the New Humanists had already, several years earlier, led a broader cultural campaign against modernism and progressive education. In calling for a recovery of exacting "standards" established by tradition, and against a modern cult of "self-expression" (as applicable to the progressive teacher as it was to modernist poetry) New Humanist critics such as Babbitt and Norman Foerster foreshadowed the reaction of the New Critics. As Eric Bennett has observed, if the New Criticism helped re-create English as a discipline in a fashion 
that would make it receptive to the idea of the creative writing program, the New Humanism helped re-create higher educational institutions in a more encompassing disciplinary fashion:

\begin{abstract}
Whereas the New Criticism insisted on the irreducible and indivisible integrity of the poem or story-every word countedthe New Humanism focused its attention on the irreducible and indivisible integrity of the humanistic subject. It did so not as a kind of progressive-educational indulgence but in deference to the wholeness of the human person and accompanied by a strict sense of good conduct (Bennett 29-30).
\end{abstract}

Foerster, a former student and chief advocate of the New Humanism after Babbitt's death, is a particularly instructive figure as he helped to establish "creative writing" as a feature of graduate training at the University of Iowa. "It exists at Iowa (and, consequently, at other American universities), "D.G. Myers claims, "only because it was originally a vital element in his thinking" (Myers 125). The New Humanism's vision of literary education as best transmitted "from the inside" by teachers trained as writers as well as critics, alert to "technical problems", facilitated the New Criticism. That it did so with reference to "enduring standards...rather than the tricks and shortcuts entailed in a merely current manner of living" (138) also betrays its congruence with the classical literary revival.

\title{
Stanford and the Classical Style
}

One of Foerster's acolytes at the University of Iowa was the young Wallace Stegner who would be among the first graduate students to benefit from the new literary culture established by the New Humanists. After being awarded a master's degree on the basis of short fiction submissions and subsequently completing a $\mathrm{PhD}$ in Foerster's School of Letters, Stegner would ultimately settle at Stanford University 
where, with the poet-critic Yvor Winters, he would help extend the influence of the classical style for the next two decades. Furthermore, Stegner would absorb not only the New Humanism's model of the writer-as-teacher-as-critic but also its conservative moralism emphasising writerly restraint, self-discipline and the capacity of individuals to challenge environmental constraints. As Eric Bennett has documented this would find pronounced expression even against the grain of certain countervailing romantic and naturalistic currents evident in his early fiction (Bennett, 123-26). ${ }^{2}$

By the time of Stegner's arrival in Palo Alto in 1945 Winters was already renowned as a critic who both adhered to fundamental precepts of the New Criticism and advocated the superiority of classical over Romantic literary traditions in even more emphatic terms than his Southern critical counterparts. His most comprehensive and still best known critical work, In Defense of Reason (1948), comprised three of his major critical collections published over the previous decade. The title itself was designed and construed as an open affirmation of the virtues of the classical understanding of art as a domain in which "emotion" should be expressed only within the limits of "reason". Winters's theories on poetry were extended to "include other literary forms with relatively unimportant qualifications" and, at base level, he defined poetry as "good in so far as it makes a defensible rational statement about a given human experience (the experience need not be real but must be in some sense possible) and at the same time communicates the emotion which ought to be motivated by that rational understanding of that experience" (Winters 11). In an essay examining the early twentieth-century American novel, Winters offers a critical account of Henry James's late prose style as an example of modernist-romantic overreach or what he perceives as its inclination towards a "supersubtlety" that itself too often descended into "obscurantism" (338). Winters 
uses this occasion, in effect, to make the case for the classical style by negative definition:

[James's] technical aim, however, seems to me unquestionably to result in a certain vitiation of the prose as prose: explicit and compact exposition or description of any kind is eliminated from the later novels, the matter that would ordinarily go into such prose being broken up and diffused in minutely discernible fragments through conversation and the miscellaneous perceptions of daily life; the attempt is made to introduce material that would ordinarily be conveyed in such prose in a manner closely resembling the manner in which it entered the experience, and perhaps hovered there, of the character in question, so that we tend strongly in the later novels, so far as the prose itself is concerned, toward the fallacy of expressive form (339-40).

Classical prose, it can be inferred from this critique, should be understood as pre-supposing some regard for "prose as prose"; a commitment to compact and relatively direct modes of exposition and description; a respect for order and selection that disbars "miscellaneous perceptions" of any type; and a scepticism as to the value of material processed via the consciousness or immediate "experience" of any given character. Winters's propagation of a "fallacy of expressive form" in opposition to what has been described as his own "classical rationalism" (Shankman 33-39) clearly couches romantic-modernist subjectivism as inferior to the "dry, hard" impersonal "objectivism" of the classical style. ${ }^{3}$

In a retrospective account of his graduate years the novelist Edward Loomishimself, as we shall see, a key figure in extending the influence of the classical stylewould describe the "consensus" (Loomis, 1985, 20) that, notwithstanding the "contrasting" (23) characters of Stegner and Winters, characterised the Stanford Writing Center in the 1950s. The general climate was one of "high pedagogy" (22) premised on a shared classroom "method". This took the form of a "formal reading, and a great one" of student work given by Stegner or Winters which was "intended to be impersonal" (21). Though both differed in their modes of delivery-Stegner sounding different voices: "the anonymous voice of the narrative as well as the 
dialogue"; Winters adopting "the standard sound of accentual-syllabic verse in English"-the effect was equally powerful on the class's “auditors" (20). In Loomis's view both teachers functioned as "formidable allies" whose "brilliant compliance" (24) powerfully shaped the style and sensibility of the Stanford program prose and poetry.

As Loomis also acknowledges, Stegner and Winters did differ in several ways not least in their own respective sources of literary inspiration. ${ }^{4}$ Whereas Winters's poetry and criticism was shaped by the formal discipline of a modern "classical" tradition that emerged from English Renaissance poetry, Stegner's fiction drew more on late nineteenth-century modes of American realism that were stylistically variegated by comparison. "Mark Twain and William Dean Howells," for example, in Loomis's view, "were the characteristic and exemplary writers of Stegner's class in the Rise of Realism" (22). Yet Stegner maintained an adherence to the technical imperatives of composition that would ultimately result in major institutional conflict by the 1960s. When the novelist-critic Albert J. Guérard took up a position in the Stanford English Department in 1961 he set about challenging Stegner's authority within the expanding domain of creative writing. Guérard was a well-connected champion of literary modernism who had secured federal funding for a new Institute of Literary Studies. The Institute gave rise to a creative writing innovation, later known as "The Voice Project", enabling working novelists to teach writing to groups of freshmen. ${ }^{5}$

The project was resented by Stegner who perceived it as a challenge to the literary values that he and others had helped embed at Stanford. The stakes of the rupture might be said to have involved more, then, than the type of customary departmental sniping over disciplinary or sub-disciplinary territory. In one sense of the term, at least, they were genuinely critical. Stegner regarded Guérard's understanding of fiction as primarily an expressionistic outlet for authorial "voice" with dismay. "Voice" was something Stegner believed that the writer achieved as a 
result of disciplined application premised on both the recognition of indispensable grammatical rules and the adoption of literary forms sanctioned by tradition. Such obligations seemingly went all the way down to the level of the sentence. In response, for instance, to Guérard's foundational view that the teacher should aim, above all, to bring out the voice of the student, Stegner stated pithily: "They might find their voice but what they don't have is syntax" (cited in Fradkin 152).

The terms in which Stegner dismissed the experimental short stories of writers such as John Hawkes, a protégé of Guérard's whom the latter brought to The Voice Project, also recall Winters' critique of Henry James's late style as impressionistic, obscure and formally incoherent. The short story, in this modern or postmodern experimental guise, Stegner laments, becomes "something authentically short, but not authentically story: an open-ended sketch, a whirling gust of images, an impression, a howl, a freehand map of the author's mind" (Ibid.). The other context for this criticism was the anarchic campus convulsions of the 1960s that, for Stegner, exacerbated such tendencies by producing in the literary sphere "a corresponding habit of incessant improvisation and a repudiation of all formal restrictions" (Stegner xvii). This shift in style and sensibility was perceived not merely as a transition between cultural moods and/or movements but as paradigmatic in social, moral and intellectual as well as more narrowly cultural terms. Indeed, the heritage in danger of being rejected stretched back to classical antiquity: "By all the evidence, we are undergoing a profound, swift change from an essentially rational (however mad) society built on Greece and Rome and a body of traditional thought painstakingly assembled, to a society which asserts itself more and more as mystical, irrational and terpsichorean" (Stegner xvi-xvii). ${ }^{6}$

Finally, then, the key flaw in texts that deviate too far from the modern "classical" template is the failure of the writer to maintain mastery over those integral elements that comprise the literary work. The criticisms aimed by Winters at Henry 
James's proto-modernism and by Stegner at the postmodern "experimentalism" of Hawkes were rooted in a perception of such works as extensions of a misconceived "Romantic" predilection towards excess, imprecision, and the "irrational". The tendency to deprecate these aspects also obviously resonates with the New Critics' demand that due diligence be paid to the precisely determined "autonomy" and structural "integrity" of literary works.

\section{The Stanford-Denver Axis}

The crucial connection between New Criticism, the New Humanism and the consolidation of a modern classical style in both prose and poetry became institutionalized in the American west in a way that was quite distinct. The connection was arguably most apparent in the career of Winters and, in particular, the pivotal role he played, with Stegner, in shaping the Stanford program. The other key figure was the poet-critic and Winters' publisher, Alan Swallow, who would help establish the University of Denver as another center of creative writing that adhered to the classical style. Swallow had studied with Robert Penn Warren and Cleanth Brooks at Louisiana State University in the late 1930s and early 1940s. Whilst being critically and artistically energised by the New Criticism at this time he was also attracted to Winters's related critique of "subjectivism" in twentieth-century poetry and prose and its critical correlate: "impressionistic" literary interpretation. Like Winters too, Swallow's anti-subjectivism was moored to a broader critique of postEnlightenment developments in philosophy. For Swallow the rot set in with the rise of a "subjective [philosophical] Idealism" that began with David Hume's denial of any connection between "the universals by which we designate knowledge... [and]...'given' sensory impressions" (Swallow, 1941, 10). By detaching sensory data 
from the realm of the universal, philosophy had effectively underwritten poetry's drift from "certain communication" (11) towards imprecision and greater dependence on an "associational method" (20). Romantic "obscurity of association" (18) had also come to define more recent movements such as modernism and surrealism that, for Swallow, reduced the artist to "the role only of recorder of the subconscious" (20).

Warren had arranged a graduate fellowship for Swallow at LSU as well as a secretarial position for Swallow's wife at the Southern Review, Brooks and Warren's relatively short-lived but highly influential outlet for the new critical precepts. It was during this time that Swallow would also commence his career as a small independent publisher, the first book bearing his imprint, Signet: An Anthology of Beginnings (1940), being a compendium of work by LSU students strongly influenced by their New Critic teachers (Cutrer, 190-91). At this time Swallow also edited the magazine Modern Verse which would publish Winters's poetry alongside that of Brooks and Warren's LSU graduates (193). Prior to the award of his doctorate on the methods of composition of the English poets of the early Renaissance in 1941, Swallow joined the faculty of the University of New Mexico where he assumed the position of poetry editor at the New Mexico Quarterly Review. Here, chiefly in authored reviews, Swallow would lay out his "classical" critical credo by praising the formal coherence of works by Winters, Warren and William Carlos Williams; the latter two figures were also criticised on occasion for producing work that deviated from classical design via a loosening of poetic structure, or by betraying elements where "perfection of pattern" was no longer discernible (Nelson 64).

After a short period at Western State College in Colorado followed by several years of military service Swallow secured a position at the University of Denver, the city where he would establish his teaching, editorial and publishing reputation. DU, largely as a result of both Swallow's influence as a publisher and his appointment as 
the first head of the creative writing program established there in 1947, would become the second western hub of the classical style. As the novelist and former graduate Mark Harris would recall: "[Swallow] gave us methods and standards from Denver...which would characterize literary study and production for the next generation: for many of us would become teachers; some would also become writers" (Harris 52). Swallow's most celebrated student would be the novelist John Williams who entered DU as an undergraduate in 1946. Soon after Williams would begin work as an assistant at the Swallow Press which would also publish his first novel Nothing But The Night (1948) and poetry collection The Broken Landscape (1949). During this period Williams would absorb New Critical and "classical" doctrine from both his mentor and Swallow Press re-issued critical works by figures such as Allen Tate and Winters.

After receiving an MA in Creative Writing at Denver in 1950 Williams would complete a PhD at the University of Missouri in Swallow's own doctoral research field: English Renaissance Courtier poetry. The reason both men remained drawn to this area was primarily because of its own earlier recovery of a "classical style". In the introduction to his 1963 anthology of Renaissance poetry Williams would write of the evolution of sixteenth century English poetry from a direct but relatively unsophisticated "Native" form to a superseding "Petrarchan" mode characterized by a diction of "fancifulness and artificial elegance" (Williams xxiii) and trivial subject matter. From the resulting "classical" synthesis - "[a] reconciliation, and finally a marriage" (xxviii) between the two traditions-something more thematically serious, stylistically compelling and formally coherent would emerge. "Gradually", Williams observed, "the naughty Cupids disappear; the language becomes more generalized and direct; the structure of the poems becomes firmer, the style more powerful, the details less decorative" (xxi). For Williams, the effects of the "not altogether...harmonious nature" (xxviii) of this "marriage" continue to shape the 
organizing principles of literary style into the twentieth century. The idiosyncratic whimsy of the worst poetry in the Petrarchan vein foreshadows the "expressionistic" excess of much modernist literary expression; likewise, the vulgar forms that largely defined the "Native" tradition prefigure the unaccomplished style, weak structures and banal treatment of theme evident in the work of some of Williams's fiction-writing peers whom he would caustically dub "Novelists in Gray Flannel Suits". ${ }^{7}$ Williams would be appointed as an assistant professor in English at DU in 1955 and shortly thereafter, with Swallow overwhelmed by the demands of his publishing and academic commitments, take over as Director of the department's creative writing program..$^{8}$

\section{Exemplars: Stoner and Mrs Bridge}

The classicism as well as what has been described as the similar "rational stoicism" that would define the position of Yvor Winters (Parkinson 133) was given comprehensive expression in what is now Williams's most well-regarded novel Stoner (1965). ${ }^{9}$ Stoner is the story of a poor farm boy whose life is radically re-oriented by the passion for literature he discovers after beginning an agriculture degree at the University of Missouri in 1910. William Stoner then steadfastly pursues a path as a teacher-scholar of literature at the same university in the face of fierce institutional pressures—namely marital obligations and the machinations of more senior faculty in the English department-that threaten to undermine his new vocation. The alliterative resonance of the eponymous character's name is itself a gesture to the novel's desire to foreground the stoic forbearance with which he meets these forces. 
As one might imagine too Stoner's literary sensibility stresses the relation between formal structures and critical inquiry in conspicuously classical terms: "he felt the logic of grammar, and he thought he perceived how it spread out from itself, permeating the language and supporting human thought" (Williams, 2003, 26). His doctoral dissertation topic turns out to be "The Influence of the Classical Tradition on the Medieval Lyric" (40). Stoner is also remarkable for the moving equanimity with which the protagonist contemplates his own mortality at the narrative's close, another attribute that can be viewed as inspired by the classical: "he wondered again at the easy, graceful manner in which the Roman lyricists accepted the fact of death, as if the nothingness they faced were a tribute to the richness of the years they had enjoyed" (40).

Given their shared institutional connections and mentors it is unlikely that Williams would have been unaware of Evan Connell by the time of the publication of the latter's first novel Mrs Bridge in 1959. Connell was in the initial class of Stegner Fellows in 1947-48 with Stegner himself selecting his first story for publication in a collection of work produced by Stanford students in 1949. ${ }^{10}$ Connell's novel had also begun life as a short story-published in a 1955 issue of The Paris Review as "The Beau Monde of Mrs Bridge"-and his first collection of stories The Anatomy Lesson (1957) had been met by the same positive reviews that would greet Mrs Bridge. The central eponymous character of Connell's novel is from a decidedly upper-middle class background which presents some contrast to the more prosaic bourgeois precincts inhabited by William Stoner. India Bridge is a "dismally bored" woman (Connell, 2004, 52), without occupation, married to a well-remunerated workaholic lawyer. As a consequence of her conventional role she struggles to find meaning in a life without emotional or vocational release. The quiet register of Connell's prose is here pressed more explicitly in the service of irony than is the case in Stoner. It is also, nonetheless, like this work, infused with a subtle sympathy for a figure who 
stoically carries out institutional obligations-be they related to the family and/or the workplace-in the face of oppressive forms of internal and external pressure. Indeed, at the outset, Mrs Bridge's deference to convention is posited as so entrenched that she would appear to be unable even to adjust to her own mildly exotic forename: "It seemed to her that her parents must have been thinking of someone else when they named her" (3).

Connell's novel closes with a tragi-comic image of entrapment: Mrs Bridge finds herself confined in a broken-down car, unable to start the engine or open a door having absent-mindedly parked too close to a garage partition. "Finally", Connell writes, "she took the keys out of the ignition and began tapping on the window, and she called to anyone who might be listening. 'Hello? Hello out there?' But no one answered, unless it was the falling snow" (187). Yet Connell is also at pains to demonstrate that Mrs Bridge yearns for the type of meaning and perspective that might be granted by a more stoic disposition. Pondering the futility of a life spent aimlessly "waiting" (rather than in stoically enduring that which must be endured) and the suddenness with which the solid things in her life will "one day, without warning, without pity...be destroyed", she also clearly craves access to more profound realms of human experience. Connell clearly moves beyond satirical intent in passages such as the following, where the existential drives and demands of "ordinary" lives are examined as scrupulously as they are in Stoner. "So it was that her thoughts now and then turned deviously deeper, spiralling down and down in search of the final recess, of life more immutable than the life she had bequeathed in the life of her children" (74). The coverage might in fact be interpreted as all the more devastating for its remorseless depiction of the thoughtless, quotidian ways such drives and demands are frustrated. 
Both Connell and Williams's novels strive to depict the broad structure and meaning of a single figure's whole life. Both of the eponymous protagonists' lives, moreover, can be viewed as relatively unremarkable and, equally, as having unfolded primarily in relatively obscure mid-Western locales: Kansas City, Missouri in the case of Bridge; Columbia, Missouri for Stoner. The pace of both novels is unhurried but deliberate; the tone mostly sedate; and the treatment of extended chronology impeccably adapted to the adopted narrative mode (be it the vignette-laden format of Mrs Bridge or the "classical" realist structure of Stoner). The major episodes play out in the historical period roughly between the 1910s and the 1950s; each, in this way, suggests the perspective of a mid-century writer in early middle age retrospectively assessing the lives of the preceding generation.

\section{Edward Loomis's “A Kansas Girl”}

A now more obscure but nonetheless key connective figure within the mid-century Stanford-Denver Axis was Edward Loomis who, like Williams and Connell, was a practitioner of both poetry and fiction. Born in Virginia in 1924, Loomis grew up and was educated in the Midwest. After serving in Europe during World War II he attended Western Reserve University in Cleveland, Ohio before being awarded a Stegner Fellowship (MA, Poetry) in 1949. He then went on to complete a PhD in English at the same institution. His first novel End of a War (1958) was drawn from his own experience as a combat infantryman involved in the final assault on Nazi Germany. The relative success of Loomis's second novel The Charcoal Horse (1959), a tale of two soldiers detained in barracks after going absent without leave and published by Swallow, enabled him to secure deals with major Eastern publishing 
houses for subsequent works. Produced in rapid succession, these were, for Knopf, the novella and short story collection Heroic Love (1960) and, for Viking, the novels The Hunter Deep in Summer (1961); The Mothers (1962); and Men of Principle (1963). Due, presumably, to underwhelming sales Loomis then returned to Swallow for the publication of a story collection Vedettes (1964) which contained what would turn out to be his single most influential literary work: "A Kansas Girl”. By the late 1960s, whilst continuing to teach English and creative writing at the University of California in Santa Barbara where he had been employed since 1958, Loomis had broken with his "classical" literary education at Stanford. In line with the tenor of the times, perhaps, he would turn decidedly more experimental literary pursuits. ${ }^{11}$

"A Kansas Girl" compresses the life story of an ordinary lower-middle class woman into a few thousand words. From her benignly Methodist upbringing to her relatively successful career as an educator and on to her quiet old-age death in the same state in which she had spent virtually all her life, Mary Rollins is depicted in the most eloquent, understated and controlled terms. The central episodes revolve around Mary's relationship with her father, himself an educator, who is at once responsible for both some of the early progress of his daughter's career but also for dissuading her from two offers of marriage, from separate suitors, that she initially was disposed to accept.

The reader is clearly prompted to ponder the various effects of this complex paternal influence but Loomis subverts this impulse in a final scene where, after her father's death and her own retirement, Mary visits the Grand Canyon. Mary's vision of this natural wonder takes a sublime celestial form; as a consequence, she undergoes an accommodation with death that is linked, in some experiential sense, to the memory, love and influence of her father. The gulf of the canyon and its colors offer "an image of heaven-the after-life, in a grandeur like that which had been 
predicted for it. Gustave Doré had illustrated heaven thus, in her father's edition of Dante-" (Loomis 221). "A Kansas Girl”, its closing passages in particular, as we shall see, would prompt a notable literary ripple that would extend into subsequent decades. The contours, tone and themes of the story, however, also obviously resonate with Connell and Williams' work.

As a result of the Swallow-Winters connection John Williams came into contact with Loomis at some point in the mid-1950s and thereafter they seem to have met up and corresponded irregularly. ${ }^{12}$ Williams soon came to regard Loomis as a first-rate novelist remarking, for example, at the close of a review of the latter's The Hunter Deep In Summer (1961): “Of the writers who have begun to make their reputations in the fifties, Loomis is among the three or four best. We cannot afford to ignore him" (JEWP, Box 21, Folder 9). The artistic basis of this appreciation can be traced back to the Stanford-Denver axis established in the 1940s and 1950s. It was primarily the promotion of a classical style by Winters and Swallow in the wake of modernist literary currents-via shared and lasting commitments to their respective programs and Swallow's small but energetic publishing enterprise-that facilitated the fiction of their two former protégés in the 1960s. A sense of generational continuity is obviously evident in Williams's appreciation of Loomis's work. Most significantly perhaps, in another unpublished review of Heroic Love, Loomis is portrayed by Williams as unusual among "post-Jamesian" novelists for both the depth of understanding that he brings to his chosen subject matter and his capacity to "embody that understanding in the form of fiction". In this respect it is the sheer range of "technical equipment" Loomis brings to bear to accomplish this mastery of form that is most striking. Unlike so many other contemporary writers "Loomis attempts to use all the resources of prose discourse-exposition, narrative, and historical summary as well as the dramatic and scenic modes." In a characterisation that rehearses once more the anti-subjectivism of both men's 
mentors Williams notes how this approach serves to distinguish Loomis from others who frequently deploy fiction "to display their own immediate reactions" to their subjects. Loomis's controlled style underwrites an approach marked by "intelligence" as opposed to "reactive" passions or emotions. Manifesting a style that is "quiet and unobtrusive, precise and yet rich with implication and consequence", Loomis achieves a degree of artistic command, according to Williams, that escapes the writer more inclined to operate "at the service of the possible eccentricities of his sensibility."

At around the same time the critical case for Loomis's work had also been taken up by his publisher. In a 1958 piece, "The Mavericks", Swallow advanced an argument for a number of novelists from western states that he took to be neglected by an Eastern literary establishment. Not all of these, necessarily, can be regarded as purveyors of the "classical style"-as the title of the piece indicates Swallow is alert to the distinct qualities of each author-but Loomis was the final figure considered and, judging by the tenor of the analysis proffered, obviously one among those that could. ${ }^{13}$ Equally, however, Swallow admits that in Loomis's work he sees the virtues "[he] has stressed throughout this essay". First among these might be said to be the type of "professionalism" in this context that the imperatives of the program era instigated among institutionally affiliated writers: "Here is a man who takes fiction quite seriously as a job to be done well". This conception of the writer as "craftsman", as McGurl notes, is characteristic of the program era : "Craft-also called 'technique' adds the elements of acquired skill and mental effort to the process, and is strongly associated with professional pride and the lessons or 'lore' of literary tradition" (McGurl 23).

Proceeding along this initial technical line of analysis Swallow noted the limpidity of Loomis's prose, the sense of "calm...immersion" it bestows on the reader. 
Contrasting End of a War with the unbridled "big blast" prose of war novels by Norman Mailer and Irwin Shaw, for example, Swallow perceives this "difference in tone" as an obvious measure of "better quality of writing". Stylistically, Loomis demonstrates a greater degree of "control" demonstrated through "quiet mastery of significant detail, sound emotion, and emerging theme" (Swallow 92). "Quiet", it should be said, is a key term within the critical vocabulary of the Stanford-Denver axis. ${ }^{14}$ Purity of diction and syntactical economy are the core units of a perfectionist ethos that extends to formal structures beyond these levels, requiring clarity of meaning and elegance of expression to converge at points of semantic equilibrium. The genuine writer is a professional who demonstrates their distinction through essentially undemonstrative means.

The quiet authority emitted by the writer's technical proficiency-evidenced via discrete narrative architecture; even, low-frequency tones; disciplined syntactical crafting-also, inevitably perhaps, manifests itself in less "technical" contexts. In addition these works share certain qualities that might best be construed as "attitudinal". Williams articulates these "non-technical" qualities by charting in his review of Loomis's A Hunter Deep in Summer, the skilful deployment of plot, setting and characterisation in the novel which is designed to facilitate exploration of grand themes connected with civilizational collapse. In the face of this understanding of the post-nuclear world as "the instrument of our failure and destruction" Williams commends the author's avoidance of "easy answers" and "conventional responses". After praising Loomis's "courage and maturity", Williams goes on to identify the philosophical provenance of this "response":

The posture before failure, decay and certain annihilation is stoical; the response is ironic; and the attitude from which posture and response spring is essentially classical...[these] are rare attitudes in modern fiction; but they are valuable attitudes, and it is good to see them embodied in a first-rate novel. (JEWP, Box 21, Folder 9) 


\section{From Loomis to Lish}

At around the same time as Williams was seeking to elevate the status of these early works, Loomis's impact was also making itself felt in a more circuitous fashion. This influence comes into view in a number of odd ways but perhaps most strikingly it manifests itself via a critical admission made by Gordon Lish in his characteristically self-referential 1995 short story, "Eats With Lentricchia and Ozick". Awaiting friends for dinner-eponymously identified as the novelist-critic Cynthia Ozick and the critic-novelist Frank Lentricchia-the unnamed narrator contemplates how he might manage the occasion in light of his wife's impending death from Lou Gehrig's disease. What possible conversation, he wonders anxiously, will he be able to muster in these circumstances? Given Lish's once commanding status as an editor and broker of several notable writers who emerged on the American literary scene in the 1970s and 1980s, the narrator's first response is noteworthy: "I thought: Tell them I just made up my mind my favourite sentence is Edward Loomis's 'Mary Rollins was born in a high white frame house shaded by elms"' (Lish, 1995, 110).

It is understandable that the mind of the author-editor-narrator would alight first on literary matters when we consider the company to be kept. That he should do so at such a seemingly granular level also makes sense if we recall Lish's renowned commitment to what his student Gary Lutz has termed the "poetics of the sentence". ${ }^{15}$ Yet the sentence derives not from a work by any notable Lish editorial client or creative writing workshop advisee-Don DeLillo, Raymond Carver or Amy Hempel to name only a few-nor from a more acknowledged source of literary influence such as James Purdy. ${ }^{16}$ It is, rather, the opening sentence to "A Kansas Girl”. Although this appreciation for Loomis's work went back to the early 1960s-in Genesis West, a post-Beat Lish-edited San Francisco based literary journal, Lish 
would recommend The Charcoal Horse to an interviewee, describing it as "the best army novel I've read" (Lish, 1964, 199)—it had nonetheless been fairly hard won.

Lish had first encountered Loomis as an undergraduate at the University of Arizona in the late 1950s where, having recently graduated from Stanford, he was employed as a writing instructor. The young student was here subjected to the kind of confrontational approach to literary composition-in this instance by a "hard case...who affected the air of Hemingway around campus" (Winters, David., 91-92)— that he himself would be associated with in later years. In an open class critique informed by "classical literary values he'd learned at Stanford" Loomis managed to reduce his pupil to tears. Lish would subsequently detail the precise creative sources of his traumatised response at this time when, a decade later, now on better terms, he would tell Loomis "that he'd trampled on his own intellectual gods-passionate individualists such as Ralph Waldo Emerson and Dylan Thomas and Jack Kerouac" (cited in Sklenicka 148). By the 1980s, Lish would acknowledge that "[Loomis] was the one who turned on the lights for me" (Hempel 93). This process of re-alignmentfrom a young romantic attachment to "passionate individualist" writers to the "classical literary values" embraced by Loomis was, then, complete by the time Lish included “A Kansas Girl” in New Sounds in American Fiction (1969).

An anthology of contemporary short stories selected by Lish for their prized technical literary attributes, New Sounds was accompanied by recordings of actors' readings of each of the stories as well as author interviews. This emphasis on the story as a form designed to be spoken and heard clearly gives expression to one by then well-established pedagogical protocol of the creative writing workshop: the classroom reading. Each story is followed by three critical sections. The first, headed "Soundings", comprises a number of often detailed questions designed to enable the implied student-reader to direct or "lead" interpretation via the application of a 
number of technical terms listed in a glossary (Lish, 1969, 11). These range from the relatively straightforward ("plot", "social setting", "theme", "style") to the more technical ("timespan", "time-progression", "limited omniscient [point of view]", "diction") to the idiosyncratic ("attack"). ${ }^{17}$ Most significant, perhaps, given the extent to which his criticism complies with its precepts is the following glossary entry: "CLASSICISM, in contemporary literature, refers to a mode of fiction in which there is a high order of balance, objectivity, restraint, and attention to form, in which reason is seen as superior to feeling" (Lish, 1969, 243). The second critical section, "Beginnings", is focused on "writing activities" (12) and offers a set of essay assignments that require a more holistic approach to the stories. The final section offers questions designed to elicit discussion of the recorded story readings and of the respective authors' own recorded reflections on their works.

Lish's preface to New Sounds reinforces these performative and affective aspects of storytelling by asserting the writer's status as a "dramatist" who operates by "invoking an effect, inviting a feeling" and who "stag[es] his discoveries" in order to "deliver [stories] to the reader whole". This latter sense of formal completion"wholeness" or "synthesis"—is posited as a crucial condition of any individual story's success. Lish nonetheless is also sensitive to the threat posed by his own more deconstructive undertaking in this context: "The editor who reduces that synthesis to its individual parts (who tries to, anyway) uncreates the work, accomplishes the destruction of its total effect and the confusion of its truth" (Lish, 1969, 7). The preface begins with a single unsourced epigraph from Loomis: "There are stories one is glad to have, and there will be more" (7). As a starting point for the theorisations that follow, it foregrounds Lish's understanding of the short story form as fundamentally intimate and "affective" in terms of reader response. For Lish, the "truth-telling" properties of the writing are symbiotically related to the "truth-feeling" capacity of the reader. The potential effects of the interaction are powerful and deeply 
personal if difficult to describe outside the discourse of the therapeutic: "I have seen it happen, seen people retrieve themselves because a certain story happened to matter-to matter to them in some immensely private kind of way. I have seen it. Not often, but often enough" (9). Once more Lish would later confess that, for himself, "A Kansas Girl" falls into this category, its power so overwhelming that he "is sometimes unable to finish it." Moreover, the story's emotional impact extends beyond the private sphere, providing him with something approximating a vocational direction: “That's it, isn't it?', [Lish] says. 'It's the thing that makes you cry [sic] you want to do" (Hempel, 93).

Indeed greater clarity as to why, in aesthetic terms, Lish was sometimes unable to finish Loomis's story can be found in his New Sounds critical commentary on the extraordinary way in which the transition from conventional life narrative to metaphysical speculation does not disrupt its "persistently reserved, solemn, even tone". The maintenance of tone is central to the "total effect" which accumulates as the story reaches its climax:

She stayed two days, and felt happy; and her trip was a success - on her return to Kansas City she was ready to die, and seven years later she accomplished this end: her mind was pure and once, in the hospital, she thought of her father, remembering how as a child she had been able to call him to her, where she lay pale and cool in the narrow bed-a good father, who would be coming toward her out of the glistening throng (Loomis 221).

The combination, in Loomis's work, of taut, controlled prose and quiet, emotional and earned metaphysical intensity is characteristic of the classical literary style he absorbed from his Stanford teachers and Denver publisher. It was a combination that Lish and, somewhat ironically perhaps, Raymond Carver, the editorial client he came to be most indelibly associated with, proved unable to resist. 


\title{
Late Carver and the Classical Style
}

The underlying stoical mood and the spare register of Loomis's "A Kansas Girl" and Williams' Stoner would seem to anticipate the work of Gordon Lish's most famous client Raymond Carver. However, if these qualities are alloyed with the dark humor that also marks Connell's Mrs Bridge then the connections would appear even more conspicuous. Indeed, in the late 60s while living in San Jose Carver spent time with Connell and would later provide a revealing account of the appeal the elder writer's precision-oriented working method retained for him:

\begin{abstract}
Evan Connell said once that he knew he was finished with a short story when he found himself going through it and taking out commas and then going through the story again putting commas back in the same places. I like that way of working on something. I respect that kind of care for what is being done. That's all we have, finally, the words, and they had better be the right ones, with the punctuation in the right places so that they can best say what they are meant to say. If the words are heavy with the writer's own unbridled emotions, or if they are imprecise and inaccurate for some other reasons-if the words are in any way blurred-the reader's eyes will slide right over them and nothing will be achieved (Carver, 1986, 24-25). ${ }^{18}$
\end{abstract}

Though Carver's characters inhabit social environs far from the haute bourgeois Midwest milieux depicted in Mrs Bridge, the subdued "quiet" style and black comic notes would be recaptured in his first collection, tellingly entitled Will You Please Be Quiet, Please? (1976). While not anthologised in New Sounds, Connell was also near the top of a list of writers whose stories Lish would have included "if th[e] book could have been made big enough to hold just a little of the best of contemporary American fiction" (Lish, 237). The decisive quality of Lish's editorial involvement in much of Carver's early fiction is now a matter of substantial record. ${ }^{19}$ 
Carver's break from Lish can also, however, be viewed within the framework of the tension between the former's "classical" urge towards emotional restraint, that is, artistically earned, context-dependent affect and the latter's view that affect was best generated by formal modes of restraint—the "minimalist" impulse. The parallels between Carver-who in his later career would seek greater degrees of stylistic and thematic texture as well as narrative complexity in his fiction-and Loomis is captured in a 2015 interview with Lish. Here, in typically provocative fashion, he dismisses such attributes as emotionally stifling "information" and instead stresses the importance of greater formal "containment":

As an editor this was the problem I had with Loomis's story 'A Kansas Girl'. I included this story-which I loved, and which always made me weepy, towards the end-in a book I published called New Sounds in American Fiction. Later, when I was working at Esquire, I wanted to reprint it. I wanted to give a gift to my teacher. But when I looked at his story with the eye of an editor rather than that of a reader, I realised I'd have to fix it. I'd have to eliminate all of it to get from the first to the last paragraph, which was so beautiful. The problem was that Loomis wasn't able to contain the thing in that given space. He had to keep going outside of it, usually for information's sake. Usually for what amounts to a kind of flashback, which is almost always the platform on which information is delivered. From my point of view, information is anathema to feeling. The more information you give the reader, the less feeling you will generate (Winters, 101).

The stylistic terrain of the Lish-Carver schism-between "minimalism", that is, economy of style, and a "precisionist" aesthetic demanding semantic exactitudewould have been familiar to students and teachers in the creative writing classrooms of mid-twentieth century Stanford and Denver. It was the determination to reconcile these demands that can be viewed as the hallmark of the classical style: the conviction that, word for word, sentence for sentence, paragraph for paragraph, there was an attainable point of elegant economy. 
It may seem counter-intuitive to consider a writer like Carver, the famed representative of "dirty realism", as a proponent of the "classical" style. However, given the thematic thrust of his blue collar tales whose characters at times appear only to be redeemed by a residual stoicism and the eloquent literary form given to their plights, Carver might well be reconsidered as such. "A Kansas Girl", in particular, might be said to have established the combination of stylistic repose in the service of representing ordinary lives with the kind of thematic reach that extends to the sphere of the numinous found in late Carver stories such as "Cathedral" and "A Small, Good Thing". Like the work and advice of those who fell directly or indirectly under the influence of the Stanford-Denver Axis-Loomis, Connell, Williams, LishCarver's late fiction was premised on the "classical" idea that the perfectibility of prose was one of few consolations left in the face of the imperfectability of man.

\section{WORKS CITED}

Bennett, Eric. Workshops of Empire: Stegner, Engle, and American Creative Writing during the Cold War. Iowa City: University of Iowa Press, 2015.

Blackwell, Matthew. "What We Talk About When We Talk About Lish" in After the Program Era: The Past, Present, and Future of Creative Writing in the University, Iowa City, IO: The University of Iowa Press, 2016.

Connell, Evan. “The Beau Monde of Mrs Bridge”, The Paris Review, Fall 1955. Mrs Bridge. London: Penguin, 2012.

Cutrer, Thomas W. Parnassus on the Mississippi: The Southern Review and the Baton Rouge Literary Community, 1935-1942. Baton Rouge, LA: Louisiana State University Press, 1984. 
Darda, Joseph. "The Philosophy of Creative Writing", Los Angeles Review of Books, February 25, 2019.

\section{https://lareviewofbooks.org/article/philosophy-creative-writing/}

Fradkin, Philip L. Wallace Stegner and the American West. Berkeley, CA: University of California Press, 2009.

Gadamer, Hans-Georg. Truth and Method. New York: Crossroad, 1986.

Groenland, Tim. The Art of Editing: Raymond Carver and David Foster Wallace. (London: Bloomsbury, 2019).

Harris, Mark. Best Father Ever Invented: The Autobiography of Mark Harris. New York: Dial Press, 1976.

Hempel, Amy. “Captain Fiction”, Vanity Fair, December 1984, 91-93, 126-28.

Hulme, T.E. "Romanticism and Classicism", reprinted in Speculations: Essays on Humanism and the Philosophy of Art, London: Kegan Paul, Trench, Trubner \& Co. Ltd, 1924.

Kindley, Evan. Poet Critics and the Administration of Culture. Cambridge, MA: Harvard University Press, 2017.

Lish, Gordon. "An Interview with Herbert Gold", Genesis West, Winter-Spring 1964, Vol. 2, Nos. 2 and 3, 187-200.

. (ed.). New Soundings in American Fiction. Menlo Park, CA: Cummings Publishing Company, 1969.

. "Eats With Lentricchia and Ozick", Salmagundi, No. 108, Fall 1995, 107-114. 
Lutz, Gary. "The Sentence is a Lonely Place", The Believer, Issue fifty-nine, January 1st, 2009.

\section{https://believermag.com/the-sentence-is-a-lonely-place/}

Loomis, Edward. "A Kansas Girl" in Lish (ed.) in New Soundings in American Fiction, 211-221.

McGurl, Mark. The Program Era: Postwar Fiction and the Rise of Creative Writing. Cambridge, MA: Harvard University Press, 2009.

Myers, D.G. The Elephants Teach: Creative Writing Since 1880. (1996). Chicago: The University of Chicago Press, 2006.

Nelson, W. Dale. The Imprint of Alan Swallow: Quality Publishing in the West. Syracuse, NY: Syracuse University Press, 2010.

Parkinson, Thomas. Hart Crane and Yvor Winters: Their Literary Correspondence. Berkeley, CA: University of California Press, 1978.

Rainey, Lawrence. "Eliot's Poetics: Classicism and Histrionics" in David E. Chinitz (ed.), A Companion to T.S. Eliot, Oxford: Wiley-Blackwell, 2009, 301-10.

Shankman, Steven. In Search of the Classic: Reconsidering the Greco-Roman Tradition, Homer to Valéry and Beyond. University Park: PA: Penn State University Press, 1994.

Shields, Charles J. The Man Who Wrote The Perfect Novel: John Williams, Stoner and the Writing Life, (Austin, TX: University of Texas Press, 2018).

Sklenicka, Carol. Raymond Carver: A Writer's Life. New York: Scribner, 2009. 
Stegner, Wallace. "Introduction" in Stegner (ed.). Twenty Years of Stanford Short Stories. Stanford, CA: Stanford University Press, 1966, ix-xx.

Swallow, Alan. "Subjectivism as Poetic Method", New Mexico Quarterly, Volume 13, Issue $1,10-20$.

.The Mavericks", Critique, Vol 2, Issue 3, Jan 1958, 74-92.

Sykes, Rachel. The Quiet Contemporary American Novel. (Manchester: Manchester University Press, 2018).

Williams, John. John Edward Williams Papers, 1944-1985. University of Arkansas Libraries: Special Collections. Manuscript Collection 716. - (ed.). English Renaissance Poetry: A Collection of Shorter Poems from Skelton to Jonson. Garden City, NY: Anchor Books, 1961. . Stoner, New York: NYRB Books, 2003.

Winters, David. “An Interview With Gordon Lish”, Critical Quarterly, Vol. 57, No. 4, 89-104.

Winters, Yvor. In Defense of Reason, Denver, CO: The Swallow Press, 1947.

Woodford, Bruce P. "Editorial”, Twentieth Century Literature, Vol. 1, No.1, April 1955.

\footnotetext{
${ }^{1}$ On the specifics and convolutions of Eliot's classicism see Rainey.

${ }^{2}$ See also Myers for a similar stress on the importance of the New Humanism on Stegner's intellectual development (154-55).

${ }^{3}$ As Shankman makes clear in his study of ancient and modern artistic instantiations of classicism, Winters's "rationalism" is not to be misconstrued as faith in "the virtually unlimited power of the utilitarian, purely quantitative, calculating reason" associated with "Enlightenment and post-Enlightenment" understandings of the term (Shankman 34). Instead, Winters's conception comes closer to the retrieval of classical reason undertaken by the political scientist Eric Voegelin-who was a friend and influence on the New Critics
} 
during his time at LSU in the 1940s-which accepts the limits of human "truth seeking" endeavours. However, this acceptance come with an acknowledgement of the extent to which truth can still be approached-if never wholly secured-by grappling with the mysteries of human experience, existence and consciousness in a "rationally defensible" manner $(12-13,30)$.

${ }^{4}$ Philip Fradkin's biography of Stegner provides a contrasting account of the personal relationship between the two men. He describes Stegner as eventually reaching a point where he "could barely tolerate Winters" and, in terms of their respective intellectual orientations, each figure as having their "own constituencies that did not mix with each other" (Fradkin 151). As to the substance of these orientations and any divergence therein, however, Fradkin says little with respect to Winters. Consequently the basis of any differences beyond those brought about Winters's sometimes difficult personality, that is, specifically literary differences, is impossible to discern.

${ }^{5}$ For a more detailed account of the significance of "The Voice Project" at Stanford see McGurl, 252-58.

${ }^{6}$ Immediately after this invocation of classical western civilization Stegner's critique also strays into some cultural commentary with pronouncedly Orientalist overtones: "In our 'advanced' echelons we are already more African than Greek; what jazz may have heralded, drugs and sexual emancipation continue and perfect” (Stegner xvii).

7 John Edward Williams Papers, 1944-1985, University of Arkansas Special Collections, Manuscript Collection 716, Box 21, Folder 9. Hereafter references will be to JEWP and cited in text. "Novelists in Gray Flannel Suits" was directed at commercially successful middlebrow novels such as Sloan Wilson's The Man in the Gray Flannel Suit (1955) and Cameron Hawley's Executive Suite (1952). For Williams these were flawed efforts to devise a postwar white collar-suburban take on the novel of manners that fell woefully short of the stylistic distinction of earlier masters of the genre such as Henry James, Edith Wharton, and Ford Madox Ford. Williams delivered the piece as a lecture on at least one occasion but it was never published.

${ }^{8}$ As well as being representative in terms of establishing a graduate creative writing program at Denver, applying for and sometimes securing foundation grants, Swallow's career was also illustrative of the transition from the "little magazine" to the "critical quarterly". After being involved with several short-lived publications of the former type as a graduate student at LSU in the late 1930s and early 1940s, in 1955 Swallow, with editor Bruce P. Woodford and editorial assistance from Williams, helped set up and published, with the Swallow Press, Twentieth Century Literature: A Scholarly and Critical Journal. In the inaugural issue's editorial Woodford would acknowledge the centrality of Swallow's "guidance" on this new "co-operative venture". The journal, he explained, "grew out of the specific and mutually felt needs of successive classes at the University of Denver" for an outlet "where not only the sources of significant critical articles but also new studies might be brought together...the most significant of scholarly and critical writing dealing with literature of the first half of our century." See Woodford (3).

${ }^{9}$ Winters's work was a major critical influence on Williams in the 1940s and 1950s. The professional relationship that they had begun to establish was, nonetheless, fatefully undermined as a consequence of a minor academic scandal involving the two men in the early 1960s. For an account of the plagiarism accusation levelled at Williams by Winters with respect to the former's introduction to an anthology of English Renaissance poetry-or what was dubbed "The Williams Affair"-see Shields (153-159).

${ }^{10}$ See "I'll Take You To Tennessee" in Stegner (ed.), Stanford Short Stories: Nineteen FortyNine, (Palo Alto, CA: Stanford University Press, 1949), 1-12. 
${ }^{11}$ The Edward Loomis archive at UCSB consists primarily of material from this later phase of his career, including audiotapes containing "tape collages", long form poetry, "found sound sources" and other audio material.

${ }^{12}$ The familiar tone of a September 1959 letter from Loomis indicates that the pair had already met at least once before-probably that summer. Loomis to Williams, September 29, 1959, Box 1, Folder 9, JEWP.

${ }^{13}$ The other figure that Swallow discusses who also obviously falls into this category is Janet Lewis, the wife of Yvor Winters with whom, in 1929-30 he co-edited a journal The Gyroscope. This short-lived publication is best known for advancing a sophisticated position that qualifiedly endorsed T.S. Eliot's call earlier in the decade for a return to classical literary values. Lewis's fiction was greatly admired by Robert Penn Warren, Wallace Stegner, John Williams and Stanford Writing Center alumni Evan Connell among others for its classical prose style and formal mastery of complex materials drawn from the historical record.

${ }^{14}$ The bearing of this term in literary contexts goes beyond the influence of creative writing institutions in the middle of the twentieth century. In her admirable critical effort to "read for quiet" in the contemporary American novel Rachel Sykes begins by offering a brief literary history of "neglected" quiet fictions that, whilst it includes coverage of Williams' Stoner, also finds its origins as a critical term in the nineteenth century and its application to classic American literary texts such as Melville's "Bartleby" and The Scarlet Letter (See Sykes, 14-47).

${ }^{15}$ The fact that Lish misremembers this sentence might itself be seen as significant in so far as it unconsciously betrays traits of the editorial approach that would underwrite the celebrated literary "minimalism" of Raymond Carver and other Lish clients/students. Loomis's story actually begins: "Mary Rollins was born in Topeka, in a high white frame house shaded by elms." As Carver's biographer notes, part of Lish's approach involved: "eliminat[ing] details that...make settings specific and intimate" (Sklenicka, 282).

${ }^{16}$ For an analysis of Purdy's influence on Lish and its bearing on the latter's editorial interventions in Carver's work see Blackwell.

17 "Attack" would establish itself as a key if somewhat under-defined term in Lish's criticaleditorial vocabulary. "Always an editor", Hempel would write memorably of her former teacher, observing him police graduate student fiction submissions, "Lish looks our work over word by word. Things we slopped over are suddenly exposed as the Word Cop patrols, catching us out at the trite, the sentimental, the fraudulent, the easy. 'Here's your attack,' he will say, skipping past a page and a half of throat clearing to the real beginning of the story" (Hempel 93).

${ }^{18}$ For details of Carver's friendship with Connell see Sklenlicka, 179.

${ }^{19}$ For a recent analysis of this editorial influence see Groenland. 


\title{
Cultivating the Classical Style:
}

\section{Edward Loomis's “A Kansas Girl” and Creative \\ Writing in the American West}

\begin{abstract}
In a characteristically self-referential 1995 short story, "Eats With Lentricchia and Ozick", Gordon Lish offered something of a critical admission in fictional garb. Awaiting friends for dinner-eponymously identified as the novelistcritic Cynthia Ozick and the critic-novelist Frank Lentricchia-the unnamed narrator contemplates how he might manage the occasion in light of his wife's impending death from Lou Gehrig's disease. What possible conversation, he wonders anxiously, will he be able to muster in these circumstances? Given Lish's once commanding status as an editor and broker of several notable writers who emerged on the American literary scene in the 1970s and 1980s, the narrator's first response is noteworthy: "I thought: Tell them I just made up my mind my favourite sentence is Edward Loomis's 'Mary Rollins was born in a high white frame house shaded by elms"' (Lish, 1995, 110).
\end{abstract}

It is understandable that the mind of the author-editor-narrator would alight first on literary matters when we consider the company to be kept. That he should do so at such a seemingly granular level also makes sense if we recall Lish's renowned commitment to what Tim Groenland has termed the "poetics of the sentence". ${ }^{1}$ More surprising, perhaps, is the source of the privileged sentence. It derives not from a work by any notable Lish editorial client or creative writing workshop advisee-Don DeLillo, Raymond Carver or Amy Hempel to name only a few-nor from a more acknowledged source of literary influence such as James Purdy. $^{2}$ It is drawn, rather, from a short story by an obscure mid-twentieth century 
writer who spent the majority of his life in northern California and who took the American West for much of his subject matter. Moreover, the significance Lish attached to this story both here and elsewhere, as this article will argue, is more important for what it reveals about reveals about the revival, entrenchment and evolution of an influential but overlooked formal variant of American fiction since World War II: the classical style.

\section{The Loomis-Lish Connection}

Born in Virginia in 1924, Edward Loomis grew up and was educated in the Midwest. After serving in Europe during World War II he attended Western Reserve University in Cleveland, Ohio before becoming one of several young, former GI writers to be awarded a Stegner Fellowship (MA, Poetry) at Stanford University in 1949 after which he undertook a PhD in English at the same institution. His first novel End of a War (1958) was drawn from his own experience as a combat infantryman involved in the final assault on Nazi Germany. The relative success of Loomis's second novel The Charcoal Horse (1959), a tale of two soldiers detained in barracks after going absent without leave, contracted to the small Denver-based publisher Alan Swallow; enabled him to secure deals with major New York City publishing houses for subsequent. Produced in rapid succession, these were, for Knopf, the novella and short story collection Heroic Love (1960) and, for Viking, the novels The Hunter Deep in Summer (1961); The Mothers (1962); and Men of Principle (1963). Due, presumably, to underwhelming sales Loomis then returned to Swallow for the publication of a story collection Vedettes (1964) which contained "A Kansas Girl". At this point, whilst continuing to teach English and creative writing at the 
University of California in Santa Barbara where he had been employed since 1958, Loomis also began to pursue a wider range of literary pursuits. ${ }^{3}$

In Genesis West, a post-Beat Lish-edited San Francisco based literary journal, Lish would recommend The Charcoal Horse to an interviewee, describing it as "the best army novel I've read" (Lish, 1964, 199). This appreciation for Loomis's work had been fairly hard won. Lish had fist encountered Loomis as an undergraduate at the University of Arizona in the late 1950s where he was employed as a writing instructor. The young student was here subjected to the kind of confrontational approach to literary composition that he himself would be associated with in later years. In an open class critique informed by "classical literary values he'd learned at Stanford" Loomis managed to reduce his pupil to tears. Lish would later detail the precise creative sources of his traumatised response at this time when, a decade later, now on better terms, he would tell Loomis "that he'd trampled on his own intellectual gods-passionate individualists such as Ralph Waldo Emerson and Dylan Thomas and Jack Kerouac" (Sklenicka 148).

As this communication suggests, Loomis's disparaging treatment of his own early efforts work did not prevent Lish from ultimately coming to appreciate his former teacher's ideas about fiction as well as his fiction itself. By the 1980s, Lish would be asserting more emphatically that "[Loomis] was the one who turned on the lights for me" (Hempel 93). This process of re-alignment-from a young romantic attachment to "passionate individualist" writers to the "classical literary values" embraced by Loomis was complete by the time Lish included "A Kansas Girl" New Sounds in American Fiction (1969). These values will be examined with reference to the historical and institutional provenance of their particulars in due course but it is worth beginning by examining the link between Lish's work as an 
educationalist in the 1960 s and the basic premise classicism as adherence to enduring formal-aesthetic principles with their origins in the classical period of western civilization.

Lish's first publication, a two volume text book English Grammar (1964), can be viewed as a broad expression of this mode of adherence to formal convention. As Mark McGurl has noted, this work presents itself as an effort to embed "a popular or populist formalism" as a pedagogical method designed to provide students "access to the unchanging order of formalism" (McGurl 290). At the same time, nonetheless, English Grammar also contains a degree of unorthodoxy in the form of sly humour, unconventional use of nouns and playful illustration of grammatical correctness. The result, what McGurl terms the text's "occasional cuteness," can also be viewed as "a modeling of the persistence of creativity even within the confines of extreme conventionality" (291) that itself prefigures the conditions of Lish's "editorial sponsorship of literary minimalism in the 1970s and 1980s" (292).

This connection between "text book" formalism and the pedagogical-editorial style Lish would develop in his later career is even more pronounced in New Sounds in American Fiction. An anthology of contemporary short stories selected by Lish for their prized technical literary attributes, New Sounds was accompanied by recordings of actors' readings of each of the stories as well as interviews with each of their respective authors. This emphasis on the story as a form designed to be spoken and heard clearly gives expression to one by then well-established pedagogical protocol of the creative writing workshop: the classroom reading. Each story is followed by three critical sections. The first, headed "Soundings", comprises a number of often detailed questions designed to enable the implied student-reader to direct or "lead" interpretation via the application of a number of technical terms listed in a glossary (Lish, 1969, 11). These range from the relatively straightforward 
Lish's preface to New Sounds reinforces these performative and affective aspects of storytelling by asserting the writer's status as a "dramatist" who operates by "invoking an effect, inviting a feeling" and who "stag[es] his discoveries" in order to "deliver [stories] to the reader whole". This latter sense of formal completion"wholeness" or "synthesis"-is posited as a crucial condition of any individual story's success. Lish nonetheless is also sensitive to the threat posed by his own more deconstructive undertaking in this context: "The editor who reduces that synthesis to its individual parts (who tries to, anyway) uncreates the work, accomplishes the destruction of its total effect and the confusion of its truth" (Lish, $1969,7)$. The preface begins with a single unsourced epigraph from Loomis: "There are stories one is glad to have, and there will be more" (7). As a starting point for the theorisations that follow, it foregrounds Lish's understanding of the short story form as fundamentally intimate and "affective" in terms of reader response. For Lish, the "truth-telling" properties of the writing are symbiotically related to the "truth-feeling" capacity of the reader. The potential effects of the interaction are powerful and deeply personal if difficult to describe outside the discourse of the therapeutic: "I have seen it happen, seen people retrieve themselves because a certain story happened to matter-to matter to them in some immensely private kind of way. I have seen it. Not often, but often enough" (9). Once more Lish would later confess that, for himself, "A Kansas Girl" falls into this category, its power so 
overwhelming that he "is sometimes unable to finish it." Moreover, the story's emotional impact extends beyond the private sphere, providing him with something approximating a vocational direction: “That's it, isn't it?', [Lish] says. 'It's the thing that makes you cry [sic] you want to do"' (Hempel, 93).

\section{"A Kansas Girl", Stanford and the New Classicism}

"A Kansas Girl" compresses the life story of an unremarkable woman from the midWest into a few thousand words. From her benignly Methodist upbringing to her relatively successful career as an educator and on to her quiet old-age death in the same state in which she had spent virtually all her life, Mary Rollins and her world is represented in the most eloquent, understated and controlled terms. The central episodes revolve around Mary's relationship with her father, himself an educator, who is at once responsible for both some of the early progress of his daughter's career but also for dissuading her from two offers of marriage, from separate suitors, that she initially seems disposed to accept.

The reader is clearly prompted to ponder the various effects of this complex paternal influence but Loomis subverts this impulse in a final scene where, after her father's death and her own retirement, Mary takes a vacation trip to the Grand Canyon. Mary's vision of this natural wonder takes a sublime celestial form; as a consequence, she undergoes an accommodation with death that is linked, in some experiential sense, to the memory, love and influence of her father. The gulf of the canyon and its colors offer "an image of heaven-the after-life, in a grandeur like that which had been predicted for it. Gustave Doré had illustrated heaven thus, in her father's edition of Dante-" (Loomis 221). Lish remarks in his New Sounds critical commentary on the extraordinary way in which the transition from conventional life narrative to metaphysical speculation does not disrupt the 
"persistently reserved, solemn, even tone". The maintenance of tone, he continues, is central to the "total effect" which accumulates as the story reaches its climax:

She stayed two days, and felt happy; and her trip was a success - on her return to Kansas City she was ready to die, and seven years later she accomplished this end: her mind was pure and once, in the hospital, she thought of her father, remembering how as a child she had been able to call him to her, where she lay pale and cool in the narrow bed-a good father, who would be coming toward her out of the glistening throng (Loomis 221).

The combination, in Loomis's work, of taut, controlled prose and quiet, emotional intensity is characteristic of the classical literary style he absorbed as a graduate student at Stanford University in the early post-war period. The style has its roots, of course, in theories and modes of art and rhetoric originating in antiquity and has famously been subject to several moments of revival in the postRenaissance era. The mainstream of twentieth-century classicism has a number of tributaries but, in the Anglo-American literary context, a key development is the emergence of the New Criticism in the 1920s and 1930s. This was informed by the English critic T.E. Hulme's distinction between "classical" and "romantic" poetics. In his essay "Romanticism and Classicism" (1911), Hulme outlined an aesthetic premised on a fresh articulation of the latter tradition-a "new classicism"-defined primarily in terms of a repudiation Romanticism. Central to both conceptions, he argued, is an understanding of human nature. For the Romantic, "man is intrinsically good, spoilt by nature"; the classical view, by contrast, conceives of human nature as "intrinsically limited, but disciplined by order and tradition to something fairly decent" (Hulme 117).

Such understandings, transplanted into the aesthetic sphere, generate a classical poetic style disciplined by the weight of tradition, and ordered by its "faithful[ness] to the conception of a limit". Romantic modes of expression, on the other hand, reject formal and thematic constraints-Hulme observes disdainfully of 
romantic poetry, in this respect, the presence of "the word infinite in every other line" (120)—and instead privilege the passionate over the dispassionate; figurative over non-figurative language; emotion over reason. In the glossary of literary terms Lish appended to New Sounds the movement would be summarised as follows: "CLASSICISM, in contemporary literature, refers to a mode of fiction in which there is a high order of balance, objectivity, restraint, and attention to form, in which reason is seen as superior to feeling" (Lish, 1969, 243).

As this implies, Hulme believed Romanticism to have been the dominant movement of the previous century but he also felt that it was about to undergo a salutary challenge from a "coming classical reaction" (119). The objective of poetry, for Hulme, as opposed to the romantic's undisciplined flights into untethered metaphor and metaphysical obscurantism, should be "accurate, precise and definite description" underwritten by a more modest conception of human nature. Poetry should be an exact but also an exacting art that requires great applicationa "state of tension or concentration of mind" that, for example, does not reject metaphor per se but demands that the poet and critic attend to those frequent moments in post-Romantic poetry when metaphorical expressions fail "to convey a physical thing and become abstract counters" (121). After World War I, Hulme was to be proven at least partially correct though the "reaction" he predicted would be complicated by the strong and varied currents of literary modernism that would also evolve alongside-and sometimes within-the classical literary revival. In addition the impact of the "new classicism" would find expression via powerful and complex means of institutional embodiment that Hulme could not have foreseen.

T.S. Eliot would undoubtedly be the best known among the younger critics to embrace or "convert" to classicism. ${ }^{5}$ However, there is a strong case to be made that the impact of this recovery among the home-based American proponents of the "New Criticism" was ultimately more far reaching. Hulme's prophesy that "a period 
of dry, hard, classical verse" was about to dawn was undoubtedly vindicated in the work of a group of poet-critics who were firmly ensconced in several major university English departments by the end of World War II. New Critics such as John Crowe Ransom, Allan Tate, Cleanth Brooks and Robert Penn Warren, all of whom were from and, initially at least, based in the South, fused the role of poet and critic and embraced a formalism that sought to dislodge the institutional power of established literary scholarship. As opposed to approaching literary interpretation via issues of biography, influence, and/or historical context the New Critics famously sought to assess the primary text in its own terms. The key was to identify, in Ransom's terminology, a work's “ontological status" by refusing to detach feeling from thought and thereby recognising poetry's unique capacity to apprehend the world and human experience in precise and accurate language. Such formalism was also incarnated in the defiantly rational structuring and deliberate diction of the poetry, fiction and criticism produced by these figures in their time.

As Evan Kindley has recently demonstrated, the New Critics were also major players among the wave of poet-critics that accrued significant cultural capital during the postwar years when English and creative writing departments became the institutional hubs of US literary life. In place of independently financed "little magazines" and small coteries of literary scholars of the 1920s, the New Criticism appealed to grant-awarding foundations, new institutionally based "critical quarterlies", and expanding graduate student programs in a new era of mass higher education. ${ }^{6}$ As Kindley argues, citing Ransom's 1948 proposal to the Rockefeller Foundation to fund the establishment of the Kenyon School of English, the aim was the creation of an institution "dedicated...to the cultivation of a specific cadre of nonelite, undereducated readers, working with the raw material of the hundreds of young soldiers back from the war with a thirst for literature" (Kindley 
138). Such students were confronted with text books such as Brooks and Warren's Understanding Poetry (1938) and Understanding Fiction (1943) that served to popularise the technical formalism of the New Criticism.

It was into this type of environment that young Edward Loomis stepped in the late 1940s on entering the Stanford graduate writing program. Loomis was, unusually at the time, a practitioner of both poetry and fiction. As such, he was a student of both novelist Wallace Stegner, who oversaw the fiction program stream, and Yvor Winters, who was responsible for poetry including the awarding of poetry fellowships. Winters was by this time more renowned as a critic who both adhered to fundamental precepts of the New Criticism and advocated the superiority of "dry hard classical verse" over Romantic traditions in even more emphatic measures than his Southern critical compatriots. His most comprehensive and still best known critical work, In Defense of Reason (1948), comprised three of his major critical collections published over the previous decade. The title itself was designed and construed as an open affirmation of the virtues of the classical understanding of art as a domain in which "emotion" should be expressed only within the limits of "reason". Winters's theories on poetry were extended to "include other literary forms with relatively unimportant qualifications" and, at base level, he defined poetry as "good in so far as it makes a defensible rational statement about a given human experience (the experience need not be real but must be in some sense possible) and at the same time communicates the emotion which ought to be motivated by that rational understanding of that experience" (Winters 11). In an essay examining the early twentieth-century American novel, Winters offers a critical account of Henry James's late prose style as an example of modernistromantic overreach or what he perceives as its inclination towards a "supersubtlety" that itself too often descended into "obscurantism" (338). Winters 
uses this occasion, in effect, to make the case for the classical style by negative definition:

[James's] technical aim, however, seems to me unquestionably to result in a certain vitiation of the prose as prose: explicit and compact exposition or description of any kind is eliminated from the later novels, the matter that would ordinarily go into such prose being broken up and diffused in minutely discernible fragments through conversation and the miscellaneous perceptions of daily life; the attempt is made to introduce material that would ordinarily be conveyed in such prose in a manner closely resembling the manner in which it entered the experience, and perhaps hovered there, of the character in question, so that we tend strongly in the later novels, so far as the prose itself is concerned, toward the fallacy of expressive form (339-40).

Classical prose, it can be inferred from this critique, should be understood as pre-supposing some regard for "prose as prose"; a commitment to compact and relatively direct modes of exposition and description; a respect for order and selection that disbars "miscellaneous perceptions" of any type; and a scepticism as to the value of material processed via the consciousness or immediate "experience" of any given character. Winters's propagation of a "fallacy of expressive form" in opposition to what has been described as his own "classical rationalism" (Shankman 33-39) prefigures the fraught classroom encounter between Loomis and Lish, the latter's romantic-modernist subjectivism running aground against the "dry, hard" impersonal "objectivism" of the classical style. 7

In a retrospective account of his Stanford years Loomis would describe the "consensus" (Loomis, 1985, 20) that, notwithstanding the "contrasting" (23) characters of his two chief instructors Stegner and Winters, characterised the Stanford Writing Center during his time there. The general climate, he recalls, was one of "high pedagogy" (22) premised on a shared classroom "method". This took the form of a "formal reading, and a great one" of student work given by Stegner or Winters which was "intended to be impersonal" (21). Though both differed in their modes of delivery-Stegner sounding different voices: "the anonymous voice of the 
narrative as well as the dialogue"; Winters adopting "the standard sound of accentual-syllabic verse in English"-the effect was equally powerful on the class's "auditors" (20). In Loomis's view both teachers functioned as "formidable allies" whose "brilliant compliance" (24) powerfully shaped a style and sensibility that, in turn, would also be transmitted to the young Gordon Lish.

As Loomis also acknowledges, Stegner and Winters did differ in several ways not least in their own respective sources of literary inspiration. ${ }^{8}$ Whereas Winters's poetry and criticism was shaped by the formal discipline of a modern "classical" tradition that emerged from English Renaissance poetry, Stegner's fiction drew more on late nineteenth-century modes of American realism that were stylistically variegated by comparison. "Mark Twain and William Dean Howells," for example, in Loomis's view, "were the characteristic and exemplary writers of Stegner's class in the Rise of Realism" (22). Yet Stegner maintained an adherence to the technical imperatives of composition that would ultimately result in major institutional conflict by the 1960s. When the novelist-critic Albert J. Guérard took up a position in the Stanford English Department in 1961 he set about challenging Stegner's authority within the expanding domain of creative writing. Guérard was a wellconnected champion of literary modernism who secured federal funding for a new Institute of Literary Studies. The Institute gave rise to a creative writing innovation that allowed for working novelists to teach writing to groups of freshmen. "The Voice Project", as it became known, and as Mark McGurl has identified, was an important development in the evolution of creative writing programs in the postwar years (McGurl 252-58).

The project was resented by Stegner who perceived it as a challenge to the literary values that he and others had helped embed at Stanford. The stakes of the rupture might be said to have involved more, then, than the type of customary sniping-in this case between English and creative writing departments-over 
disciplinary or sub-disciplinary territory. In one sense of the term at least they were genuinely critical. Stegner regarded Guérard's endorsement of fiction designed primarily as an expressionistic outlet for authorial "voice" with dismay. "Voice" was something Stegner believed that the writer achieved as a result of disciplined application premised on both the recognition of indispensable grammatical rules and the adoption of literary forms sanctioned by tradition. In a fashion that would seem to presage Lish's micro-formal pre-occupations, such obligations went all the way down to the level of the sentence. In response, for instance, to Guérard's foundational view that the teacher should aim, above all, to bring out the voice of the student, Stegner stated pithily: "They might find their voice but what they don't have is syntax" (cited in Fradkin 152).

The terms in which Stegner dismissed the experimental short stories of writers such as John Hawkes, a protégé of Guérard's whom the latter brought to The Voice Project in the mid-1960s, also recall Winters's critique of James's late style as impressionistic, obscure and formally incoherent. The short story, in this modern or postmodern experimental guise, Stegner laments, becomes "something authentically short, but not authentically story: an open-ended sketch, a whirling gust of images, an impression, a howl, a freehand map of the author's mind" (Ibid.). The other context for this criticism was the anarchic campus convulsions of the 1960s that, for Stegner, exacerbated such tendencies by generating in the literary sphere "a corresponding habit of incessant improvisation and a repudiation of all formal restrictions" (Stegner xvii). This shift in style and sensibility was perceived not merely as a transition between cultural moods and/or movements but as paradigmatic in social, moral and intellectual as well as more narrowly cultural terms. The heritage in danger of being rejected stretched back to classical antiquity: "By all the evidence, we are undergoing a profound, swift change from an essentially rational (however mad) society built on Greece and Rome and a body of 
traditional thought painstakingly assembled, to a society which asserts itself more and more as mystical, irrational and terpsichorean" (Stegner xvi-xvii). ${ }^{9}$

Finally, then, the key flaw in texts that deviate too far from the modern "classical" template is the failure of the writer to maintain control or mastery over those integral elements that comprise the literary work. Loomis' treatment of the young Thomas Wolfe and Beats-infatuated Lish is an illustration of this tension but the accusations could also be directed at works where the regrettable legacy of Romanticism was less obvious. The criticisms aimed by Winters at Henry James's proto-modernism and by Stegner at the postmodern "experimentalism" of Hawkes were rooted in a perception of such works as extensions of a misconceived "Romantic" predilection towards excess, imprecision, and the "irrational". The tendency to deprecate these aspects also obviously resonates with the New Critics' demand that due diligence be paid to the precisely determined "autonomy" and structural "integrity" of a literary work.

\section{The Stanford-Denver Axis}

The crucial connection between New Criticism and the consolidation of a modern classical style in both prose and poetry became institutionalized in the American west in a way that was quite distinct. The connection was arguably most apparent in the career of Winters and, in particular, the pivotal role he played, with Stegner, in shaping the Stanford creative writing program. The other key figure was the poet-critic and publisher of Loomis and Winters, Alan Swallow, who studied with Robert Penn Warren and Cleanth Brooks at Louisiana State University in the late 1930 s and early 1940s. Swallow was critically and artistically energised by the New Criticism but also adhered closely to Winters's related critique of "subjectivism" in 
twentieth-century poetry and prose and its critical correlate "impressionistic" literary interpretation. Like Winters too, his anti-subjectivism was moored to a broader critique of post-Enlightenment developments in philosophy. For Swallow the rot set in with the rise of "subjective [philosophical] Idealism" that began with David Hume's denial of any connection between "the universals by which we designate knowledge... [and]...'given' sensory impressions” (Swallow, 1941, 10). By detaching sensory data from the realm of the universal philosophy had effectively underwritten poetry's drift from "certain communication" (11) towards imprecision and greater dependence on an "associational method" (20). Romantic "obscurity of association" (18) has also come to define more recent movements such as modernism and surrealism that, for Swallow, reduce the artist to "the role only of recorder of the subconscious" (20).

Warren had arranged a graduate fellowship for Swallow at LSU as well as a secretarial position for Swallow's wife at the Southern Review, Brooks and Warren's relatively short-lived but highly influential outlet for the new critical precepts. It was during his time in Baton Rouge that Swallow would begin his publishing career, the first work bearing his imprint, Signet: An Anthology of Beginnings (1940), being a compendium of work by LSU students strongly influenced by their New Critic teachers (Cutrer, 190-91). At this time Swallow also edited the magazine Modern Verse which would publish Winters's poetry alongside that of Brooks and Warren's LSU graduates (193). Prior to the award of his doctorate on the methods of composition of the English poets of the early Renaissance in 1941, Swallow joined the faculty of the University of New Mexico where he assumed the position of poetry editor at the New Mexico Quarterly Review. Here, chiefly in authored reviews, Swallow would lay out his "classical" critical credo by praising the formal coherence of works by Winters, Warren and William Carlos Williams; the latter two figures were also criticised on occasion for producing work that deviated from classical 
design via a loosening of poetic structure, or by betraying elements where “perfection of pattern" was no longer discernible (Nelson 64).

After a short period at Western State College in Colorado followed by several years of military service Swallow secured a position at the University of Denver, the city where he would establish his teaching, editorial and publishing reputation. DU, initially as a result of Swallow's influence as a publisher first head of the creative writing program established there in 1947, would become another western hub of the classical style. As the novelist and former graduate Mark Harris would recall: "[Swallow] gave us methods and standards from Denver...which would characterize literary study and production for the next generation: for many of us would become teachers; some would also become writers" (Harris 52). Swallow's most celebrated student would be the novelist John Williams who entered DU as an undergraduate in 1946. Williams would work as an assistant at the Swallow Press which would also publish his first novel Nothing But The Night (1948) and poetry collection The Broken Landscape (1949). During this period Williams would absorb New Critical and "classical" doctrine from his mentor and from Swallow Press reissued critical works by figures such as Allen Tate and Winters.

After completing an MA in Creative Writing at Denver in 1950 Williams would complete a PhD at the University of Missouri in Swallow's own doctoral research field: English Renaissance Courtier poetry. The reason both men remained drawn to this area was primarily because of its recovery of a "classical" style. In the introduction to his 1963 anthology of Renaissance poetry Williams would write of the evolution of sixteenth century English poetry from a direct but relatively unsophisticated "Native" form to a superseding "Petrarchan" mode characterized by a diction of "fancifulness and artificial elegance" (Williams xxiii) and trivial subject matter. From the resulting "classical" synthesis— "[a] reconciliation, and finally a 
marriage" (xxviii) between the two traditions-something more thematically serious, stylistically compelling and formally coherent would emerge. "Gradually", Williams observed, "the naughty Cupids disappear; the language becomes more generalized and direct; the structure of the poems becomes firmer, the style more powerful, the details less decorative" (xxi). For Williams, the effects of the "not altogether...harmonious nature" (xxviii) of this "marriage" continue to shape the organizing principles of literary style into the twentieth century. The idiosyncratic whimsy of the worst poetry in the Petrarchan vein foreshadows the "expressionistic" excess of much modernist literary expression; likewise, the vulgar forms that largely defined the "Native" tradition prefigure the unaccomplished style, weak structures and banal treatment of theme evident in the work of some of Williams's fiction-writing peers whom he would caustically label "Novelists in Gray Flannel Suits". 10

As a result of the Swallow-Winters connection Williams came into contact with Edward Loomis at some point in the mid-1950s and thereafter they met up and corresponded irregularly. ${ }^{11}$ Williams quickly came to view Loomis as a first-rate novelist remarking, for example, at the close of a review of the latter's The Hunter Deep In Summer (1961): "Of the writers who have begun to make their reputations in the fifties, Loomis is among the three or four best. We cannot afford to ignore him" (JEWP, Box 21, Folder 9). The artistic basis of this appreciation can be traced back to the Stanford-Denver axis established in the 1940s and 1950s. It was primarily the promotion of a classical style by Winters and Swallow in the wake of modernist literary currents-via shared and lasting commitments to their respective creative writing programs and Swallow's small but energetic publishing enterprise-that facilitated the fiction of their two former protegés in the 1960s. A sense of generational continuity is evident in Williams's response to Loomis's work. Most significantly perhaps, in another unpublished review of Heroic Love, Loomis is 
portrayed by Williams as unusual among "post-Jamesian" novelists for both the depth of understanding that he brings to his chosen subject matter and his capacity to "embody that understanding in the form of fiction". In this respect it is the sheer range of "technical equipment" Loomis brings to bear to accomplish this mastery of form that is most striking. Unlike so many other contemporary writers "Loomis attempts to use all the resources of prose discourse-exposition, narrative, and historical summary as well as the dramatic and scenic modes." In a characterisation that rehearses once more the anti-subjectivism of his mentors Williams notes how this approach serves to distinguish Loomis from writers who too frequently deploy fiction "to display their own immediate reactions" to their subjects. Loomis's controlled style underwrites an approach marked by "intelligence" as opposed to "reactive" passions or emotions. Manifesting a style that is "quiet and unobtrusive, precise and yet rich with implication and consequence", Loomis achieves a degree of artistic command that escapes the writer more inclined to operate "at the service of the possible eccentricities of his sensibility."

At around the same time the critical case for Loomis's work had also been taken up by his publisher. In a 1958 piece, "The Mavericks", Alan Swallow advanced an argument for a number of novelists from western states that he took to be neglected by an Eastern literary establishment. Not all of these, necessarily, can be regarded as purveyors of the "classical style"-as the title of the piece indicates Swallow is alert to the distinct qualities of each author-but Loomis was the final figure considered and, judging by the tenor of the analysis proffered, obviously one among those that could. ${ }^{12}$ Equally, however, Swallow admits that in Loomis's work he sees the virtues "[he] has stressed throughout this essay". First among these might be said to be the type of "professionalism" in this context that the imperatives of the program era instigated among institutionally affiliated 
writers: "Here is a man who takes fiction quite seriously as a job to be done well". This conception of the writer as "craftsman", as McGurl notes, is characteristic of the program era : “Craft—also called 'technique' adds the elements of acquired skill and mental effort to the process, and is strongly associated with professional pride and the lessons or 'lore' of literary tradition" (McGurl 23).

Proceeding along this initial technical line of analysis Swallow noted the limpidity of Loomis's prose, the sense of "calm...immersion" it bestows on the reader. Contrasting End of a War with the unbridled "big blast" prose of war novels by Norman Mailer and Irwin Shaw, for example, Swallow perceives this "difference in tone" as an obvious measure of "better quality of writing". Stylistically, Loomis demonstrates a greater degree of "control" demonstrated through "quiet mastery of significant detail, sound emotion, and emerging theme" (Swallow 92). "Quiet", it should be said, is a key term within the critical vocabulary of the Stanford-Denver axis. Purity of diction and syntactical economy are the core units of a perfectionist ethos that extends to formal structures beyond these levels, requiring clarity of meaning and elegance of expression to converge at point of semantic equilibrium. The genuine writer is a professional whose demonstrates its distinction through essentially undemonstrative means. The quiet authority emitted by the writer's technical proficiency-evidenced via discrete narrative architecture, even lowfrequency tone, disciplined syntactical crafting-also inevitably, manifests itself in less "technical" contexts. Such extraordinary congruence of theme and setting, as well as style and form, for example, is evident between Loomis's "A Kansas Girl" and two novels published by figures equally shaped by Stanford-Denver classical values: Evan Connell's Mrs Bridge (1959) and John Williams's Stoner (1965).

\section{Mrs Bridge and Stoner}


Both Connell and Williams's novels strive, like Loomis's story, to depict the larger part of a single figure's life. Each of the protagonists, moreover-Mary Rollins, India Bridge and William Stoner-are distinguished by relatively unremarkable lives lived, for the most part in relatively obscure mid-Western locales: Kansas City, Missouri in the case of Bridge; Columbia, Missouri for Stoner; and various small towns and cities in Kansas for Rollins. The pace of each work, notwithstanding the short story form of "A Kansas Girl" and multiple vignette structure of Mrs Bridge, is unhurried but deliberate, the tone sedate, and the treatment of extended chronology impeccably adapted to the adopted narrative mode. The major episodes within each story play out in the historical period roughly between the 1910s and the 1950s; each, in this way, suggests the perspective of a mid-century writer in early middle age retrospectively assessing the lives of the preceding generation.

In addition these works share certain qualities that might best be construed as "attitudinal". Williams articulates these "non-technical" qualities by charting in his review of Loomis's A Hunter Deep in Summer, the skilful deployment of plot, setting and characterisation in the novel which is designed to facilitate exploration of grand themes connected with civilizational collapse. In the face of this understanding of the post-nuclear world as "the instrument of our failure and destruction" Williams commends the author's avoidance of "easy answers" and "conventional responses". After praising Loomis's "courage and maturity", Williams goes on to identify the philosophical provenance of this "response":

The posture before failure, decay and certain annihilation is stoical; the response is ironic; and the attitude from which posture and response spring is essentially classical...[these] are rare attitudes in modern fiction; but they are valuable attitudes, and it is good to see them embodied in a first-rate novel. (JEWP, Box 21, Folder 9) 
The classicism as well as what has been described as the similar "rational stoicism" that would define the position of Loomis's former teacher at Stanford Yvor Winters (Parkinson 133) was given even more comprehensive expression in Stoner, the novel Williams himself was working on at the time of this review. Stoner is the story of a poor farm boy whose life is radically re-oriented by the passion for literature he discovers after beginning an agriculture degree at the University of Missouri in 1910. William Stoner then pursues a path as a teacher-scholar of literature at the same university in the face of fierce institutional pressuresnamely marital obligations and the machinations of more senior faculty in the English department-that threaten to undermine his new vocation. The alliterative resonance of the eponymous character's name is itself a gesture to the novel's aim to foreground the stoic forbearance with which he meets these forces.

As one might imagine too Stoner's literary sensibility stresses the relation between formal structures and critical inquiry in conspicuously classical terms: "he felt the logic of grammar, and he thought he perceived how it spread out from itself, permeating the language and supporting human thought" (Williams, 2003, 26). His doctoral dissertation topic turns out to be "The Influence of the Classical Tradition on the Medieval Lyric" (40). Like "A Kansas Girl", Stoner is also remarkable for the moving equanimity with which the protagonist greets their death at the narrative's close. The response, as Stoner's reflections attest, can be viewed again as classical in origin: "he wondered again at the easy, graceful manner in which the Roman lyricists accepted the fact of death, as if the nothingness they faced were a tribute to the richness of the years they had enjoyed" (40).

Given their shared institutional connections and mentors it is unlikely that Loomis or Williams would have been unaware of Evan Connell by the time of the publication of his first novel Mrs Bridge in 1959. Connell was in the first class of 
Stegner fellows in 1947-48 with Wallace Stegner himself selecting his first story for publication in a collection of work produced by Stanford Writing Center students in 1949. ${ }^{13}$ Connell's novel had also begun life as a short story-published in a 1955 issue of the The Paris Review as "The Beau Monde of Mrs Bridge"-and his first collection of stories The Anatomy Lesson (1957) had been met by the same positive reviews that greeted Mrs Bridge. The central eponymous character of Connell's novel is from a decidedly upper-middle class background which presents some contrast to the lesser middle class precincts inhabited by William Stoner and Mary Rollins. India Bridge is a "dismally bored" woman (Connell, 2004, 52), without occupation, married to a well-remunerated workaholic lawyer. As a consequence of her conventional role she struggles to find meaning in a life without emotional or vocational release. The quiet register of Connell's prose is here pressed more explicitly in the service of irony than is the case with Williams or Loomis's work. It is also, nonetheless, like this work, infused with a subtle sympathy for a figure who stoically carries out institutional obligations - in the family, the workplace-in the face of oppressive types of internal and external pressures. Indeed, at the outset Mrs Bridge's deference to convention is posited as so entrenched that she would appear to be unable even to adjust to her own mildly exotic forename: "It seemed to her that her parents must have been thinking of someone else when they named her" (3).

Connell's novel closes with a tragi-comic image of entrapment: Mrs Bridge finds herself confined in a broken-down car, unable to start the engine or open a door having absent-mindedly parked too close to a garage partition. "Finally", Connell writes, "she took the keys out of the ignition and began tapping on the window, and she called to anyone who might be listening. 'Hello? Hello out there?' But no one answered, unless it was the falling snow" (187). Yet Connell is also at pains to demonstrate that Mrs Bridge yearns for the type of meaning and 
perspective that might be granted by a more stoic disposition. Pondering the futility of a life spent aimlessly "waiting" (rather than in stoically enduring that which must be endured) and the suddenness with which the solid things in her life will "one day, without warning, without pity...be destroyed", she also clearly craves access to more profound realms of human experience. Connell clearly here moves beyond satirical intent in passages such as the following, where the existential drives and demands of "ordinary" lives are examined as scrupulously as they are anywhere in Stoner or "A Kansas Girl". "So it was that her thoughts now and then turned deviously deeper, spiralling down and down in search of the final recess, of life more immutable than the life she had bequeathed in the life of her children" (74). The coverage might in fact be interpreted as all the more devastating for its remorseless depiction of the thoughtless, quotidian ways such drives and demands are frustrated.

\section{Afterlife: “A Kansas Girl” and Late Carver}

The dark humor, the underlying stoical mood and the spare register of Connell's prose would also seem to anticipate the work of Gordon Lish's most famous client Raymond Carver. ${ }^{14}$ Though Carver's characters inhabit social environs far from the haute bourgeois Midwest milieux depicted in Mrs Bridge, the subdued "quiet" style and black comic notes would be recaptured in his first collection, tellingly entitled Will You Please Be Quiet, Please? (1976). While not anthologised in New Sounds, Connell was also near the top of a list of writers whose stories, by Lish's own admission, would have been included "if this book could have been made big enough to hold just a little of the best of contemporary American fiction" (Lish, 
237). Lish's editorial involvement in much of Carver's early fiction is now a matter of substantial record. Yet the tension between "minimalism", that is, economy of style, and a "precisionist" aesthetic demanding semantic exactitude is one that would have been familiar to students and teachers in the creative writing classrooms of Stanford and Denver. It was the determination to reconcile these sometimes opposing demands that can be viewed as the hallmark of the classical style: the conviction that, word for word, sentence for sentence, paragraph for paragraph, there was an attainable point of elegant economy. It may seem counterintuitive to consider a writer like Carver, the famed representative of "dirty realism", as a proponent of the "classical" style. However, given the thematic thrust of his blue collar tales whose characters at times appear only to be redeemed by the eloquent literary form given to their plights, Carver should perhaps be reconsidered as such. "A Kansas Girl", in particular, might be said to have established the combination of stylistic repose in the service of representing ordinary lives and thematic reach that extends to the sphere of the numinous found in late Carver stories such as "Cathedral". Like the work of those who fell directly or indirectly under the influence of the Stanford-Denver axis-Loomis, Connell, Williams, LishCarver's late fiction was premised on the "classical" idea that the perfectibility of prose was one of few consolations given the imperfectability of man.

\section{WORKS CITED}


Blackwell, Matthew. "What We Talk About When We Talk About Lish" in After the Program Era: The Past, Present, and Future of Creative Writing in the University, Iowa City, IO: The University of Iowa Press, 2016.

Connell, Evan. "The Beau Monde of Mrs Bridge”, The Paris Review, Fall 1955. . Mrs Bridge. London: Penguin, 2012.

Cutrer, Thomas W. Parnassus on the Mississippi: The Southern Review and the Baton Rouge Literary Community, 1935-1942. Baton Rouge, LA: Louisiana State University Press, 1984.

Fradkin, Philip L. Wallace Stegner and the American West. Berkeley, CA: University of California Press, 2009.

Groenland, Tim. “The Poetics of the Sentence: Examining Gordon Lish's Literary Legacy", Irish Journal of American Studies, (Issue 4), 2015. On-line. www.ijas.iaas.ie/?issue $=$ issue-4

Harris, Mark. Best Father Ever Invented: The Autobiography of Mark Harris. New York: Dial Press, 1976.

Hempel, Amy. “Captain Fiction”, Vanity Fair, December 1984, 91-93, 126-28.

Hulme, T.E. "Romanticism and Classicism", reprinted in Speculations: Essays on Humanism and the Philosophy of Art, London: Kegan Paul, Trench, Trubner \& Co. Ltd, 1924.

Kindley, Evan. Poet Critics and the Administration of Culture. Cambridge, MA: Harvard University Press, 2017.

Lish, Gordon. "An Interview with Herbert Gold”, Genesis West, Winter-Spring 1964, Vol. 2, Nos. 2 and 3, 187-200. 
- (ed.). New Soundings in American Fiction. Menlo Park, CA: Cummings Publishing Company, 1969.

. "Eats With Lentricchia and Ozick", Salmagundi, No. 108, Fall 1995, 107-114.

Loomis, Edward. "A Kansas Girl" in Lish (ed.) in New Soundings in American Fiction, 211-221.

. "Wallace Stegner and Yvor Winters as Teachers", North Dakota Review, volume 23, number 4, Winter 1985, 19-24.

McGurl, Mark. The Program Era: Postwar Fiction and the Rise of Creative Writing. Cambridge, MA: Harvard University Press, 2009.

Nelson, W. Dale. The Imprint of Alan Swallow: Quality Publishing in the West. Syracuse, NY: Syracuse University Press, 2010.

Parkinson, Thomas. Hart Crane and Yvor Winters: Their Literary Correspondence. Berkeley, CA: University of California Press, 1978.

Rainey, Lawrence. "Eliot's Poetics: Classicism and Histrionics" in David E. Chinitz (ed.), A Companion to T.S. Eliot, Oxford: Wiley-Blackwell, 2009, 301-10.

Shankman, Steven. In Search of the Classic: Reconsidering the Greco-Roman Tradition, Homer to Valéry and Beyond. University Park: PA: Penn State University Press, 1994.

Sklenicka, Carol. Raymond Carver: A Writer's Life. New York: Scribner, 2009.

Stegner, Wallace. "Introduction" in Stegner (ed.). Twenty Years of Stanford Short Stories. Stanford, CA: Stanford University Press, 1966, ix-xx.

Swallow, Alan. "Subjectivism as Poetic Method", New Mexico Quarterly, Volume 13, Issue $1,10-20$. 
Williams, John. John Edward Williams Papers, University of Arkansas. . (ed.). English Renaissance Poetry: A Collection of Shorter Poems from Skelton

${ }^{1}$ The fact that Lish misremembers this sentence might itself be seen as significant in so far as it unconsciously betrays traits of the editorial approach that would underwrite the celebrated literary "minimalism" of Raymond Carver and other Lish clients/students. Loomis's story actually begins: "Mary Rollins was born in Topeka, in a high white frame house shaded by elms." As Raymond Carver's biographer notes, part of Lish's approach involved: "eliminat[ing] details that...make settings specific and intimate" (Sklenicka, 282).

${ }^{2}$ For an analysis of Purdy's influence on Lish and its bearing on the latter's editorial interventions in Carver's work see Blackwell.

${ }^{3}$ The Edward Loomis archive at UCSB comprise primarily of material from this later phase of his career, including audiotapes containing "tape collages", long form poetry, "found sound sources" and other audio material in a more experimental literary vein.

4 "Attack" would establish itself as a key if somewhat under-defined term in Lish's criticaleditorial vocabulary. "Always an editor", Hempel would write memorably of her former teacher, observing him police graduate student fiction submissions, "Lish looks our work over word by word. Things we slopped over are suddenly exposed as the Word Cop patrols, catching us out at the trite, the sentimental, the fraudulent, the easy. 'Here's your attack,' he will say, skipping past a page and a half of throat clearing to the real beginning of the story" (Hempel 93).

${ }^{5}$ On the specifics and convolutions of Eliot's classicism see Rainey.

${ }^{6}$ As well as being representative in terms of establishing a graduate creative writing program at Denver, applying for and sometimes securing foundation grants, Alan Swallow's career is also illustrative of the transition from the "little magazine" to the "critical quarterly". After being involved with several short-lived publications along the former lines whilst a graduate student at LSU in the late 1930s and early 1940s, by 1955 Swallow, with editor Bruce P. Woodford and editorial assistance from John Williams, had helped set up and had begun to publish, with the Swallow Press, Twentieth Century Literature: A Scholarly and Critical Journal. In the inaugural issue editorial Woodford would acknowledge the centrality of Swallow's "guidance" on this new "co-operative venture". The journal, he explained, "grew out of the specific and mutually felt needs of successive classes at the University of Denver" for an outlet "where not only the sources of significant critical articles but also new studies might be brought together...the most significant of scholarly and critical writing dealing with literature of the first half of our century." Bruce P. Woodford, "Editorial", Twentieth Century Literature, Vol. 1, No.1, April 1955, 3.

${ }^{7}$ As Shankman makes clear in his study of ancient and modern artistic instantiations of classicism, Winters's "rationalism" is not to be misconstrued as faith in "the virtually 
unlimited power of the utilitarian, purely quantitative, calculating reason" associated with "Enlightenment and post-Enlightenment" understandings of the term (Shankman 34). Instead, Winters's conception comes closer to the retrieval of classical reason undertaken by the political scientist Eric Voegelin-who was a friend and influence on the New Critics during his time at LSU in the 1940s-which accepts the limits of human "truth seeking" endeavours. However, this acceptance come with an acknowledgement of the extent to which truth can still be approached-if never wholly secured-by grappling with the mysteries of human experience, existence and consciousness in a "rationally defensible" manner $(12-13,30)$.

${ }^{8}$ Philip Fradkin's biography of Stegner provides a contrasting account of the personal relationship between the two men. He describes Stegner as eventually reaching a point where he "could barely tolerate Winters" and, in terms of their respective intellectual orientations, each figure as having their "own constituencies that did not mix with each other" (Fradkin 151). As to the substance of these orientations and any divergence therein, however, Fradkin says little with respect to Winters. Consequently the basis of any differences beyond those brought about Winters's sometimes difficult personality, that is, specifically literary differences, is impossible to discern.

${ }^{9}$ Immediately after this invocation of classical western civilization Stegner's critique also strays into some cultural commentary with pronounced Orientalist overtones: "In our 'advanced' echelons we are already more African than Greek; what jazz may have heralded, drugs and sexual emancipation continue and perfect” (Stegner xvii).

${ }^{10}$ John Edward Williams Papers, 1944-1985, University of Arkansas Special Collections, Manuscript Collection 716, Box 21, Folder 9. Hereafter references will be to JEWP and cited in text. "Novelists in Gray Flannel Suits" was directed at commercially successful middlebrow novels such as Sloan Wilson's The Man in the Gray Flannel Suit (1955) and Cameron Hawley's Executive Suite (1952). For Williams these were flawed efforts to devise a postwar white collar-suburban take on the novel of manners that fell woefully short of the stylistic distinction of earlier masters of the genre such as Henry James, Edith Wharton, and Ford Madox Ford. Williams delivered the piece as a lecture on at least one occasion but appears not to ever have been published.

${ }^{11}$ The familiar tone of a September 1959 letter from Loomis indicates that the pair had already met at least once before-probably that summer. Loomis to Williams, September 29, 1959, Box 1, Folder 9, JEWP.

${ }^{12}$ The other figure that Swallow discusses who also obviously falls into this category is Janet Lewis, the wife of Yvor Winters with whom, in 1929-30 he co-edited a journal The Gyroscope. This short-lived publication is best known for advancing a sophisticated position that qualifiedly endorsed T.S. Eliot's call earlier in the decade for a return to classical literary values. Lewis's fiction was greatly admired by Robert Penn Warren, Wallace Stegner, John Williams and Stanford Writing Center alumni Evan Connell among others for its classical prose style and formal mastery of complex materials drawn from the historical record.

${ }^{13}$ See "I'll Take You To Tennessee" in Stegner (ed.), Stanford Short Stories: Nineteen FortyNine, (Palo Alto, CA: Stanford University Press, 1949), 1-12.

${ }^{14}$ During a period spent in and around San Jose in the late 1960s and 1970s Carver, his wife Maryann and sister-in-law Amy Burk were friendly with Connell. See Sklenlicka, 179. 